\title{
Archives of Oral Biology \\ Dental health in adults and subadults from the 16th-century plague cemetery of Alghero (Sardinia, Italy) \\ --Manuscript Draft--
}

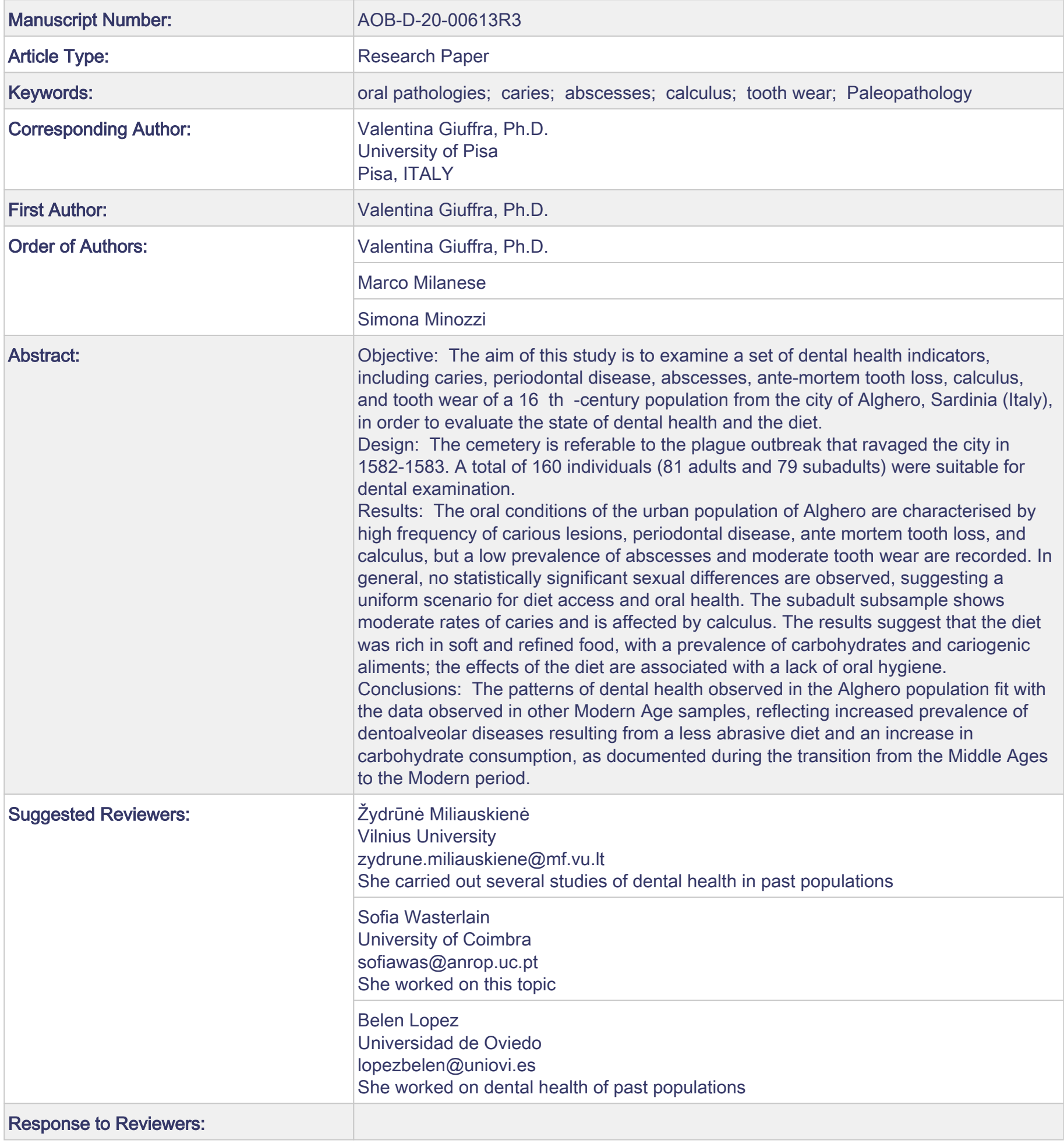


Dear Editor,

following your suggestion we resubmit as a new submission the manuscript No. AOB-D-20-00340.

This research examines a set of dental health indicators, including caries, periapical lesions, periodontal disease, ante-mortem tooth loss, calculus, and tooth wear of a population of Early Modern period from the city of Alghero, Sardinia (Italy).

The manuscript has been revised according to the reviewers and editor's comments. Below in bold type a detailed list of the changes and the rebuttal against each point.

We wonder if you could be interested in publishing this new version of the manuscript in the Archives of Oral Biology.

Yours sincerely,

Giuffra Valentina, PhD

Division of Paleopathology

Department of Translational Research on New Technologies in Medicine and Surgery University of Pisa, Italy

Via Roma 57

Tel. 0039050992894 ; fax: 0039050992706

\section{$\underline{\text { Reviewer \#1: }}$}

This is a quite interesting, and pretty straightforward study of dento-alveolar lesions in the Early Modern population from Sardinia. The biggest importance of this analysis is that it represents, as the authors themselves say, "...a catastrophic cemetery and therefore can provide an unbiased picture of the demographic and epidemiological characteristics of the original live population". In other words, the sample in question (Alghero) represents the victims of the plague outbreak of 1582-1583.

The paper is well-written, with some minor grammar and spelling errors (I'd recommend finding a native English speaker to proof-read it). The manuscript is logically organised with clearly defined research questions, while the methods used in the paper are appropriate and fairly standard for this type of research. The sample size used in the study is appropriate and I particularly like that the authors used subadult individuals to study certain lesions and this is not done very often is similar analyses. This paper successfully arranges and presents the rich new data into the framework already known from the similar studies across Europe, although it still suffers from several major and minor problems.

Here, I will try to list my suggestions/comments on certain parts of the text:

1) page 3 , lines 49-51 - the definition of periapical lesions is too short, you have to broaden it. Besides, there needs to be at least one reference here. Additionally, you might mention that the term "abscess" will be also used as you use it later in the text.

Reply: The definition of periapical lesion and abscess was broaden and improved with the addition of references and the term abscess was mentioned.

2) page 3, lines 53-54 - please, make a clear distinction between periapical lesions and periodontal disease. Maybe you could use some other term for periodontal disease such as "alveolar resorption" to avoid any misunderstandings.

Reply: the term "periapical lesions" was substituted with "abscesses", in order to avoid misunderstandings and more details on periapical lesions and periodontal diseases were 
provided.

3) page 4, lines 9-12 - please, provide more details on how periodontal disease can be evaluated as potential indicator of carbohydrates consumption in the diet.

Reply: more details were provided.

4) page 4, lines 36-39 - here you state that "In this study, the presence and severity of calculus deposits are considered in relation with caries and periodontal disease" but you never touched on this subject in the discussion section. Therefore, a sentence or two dealing with this subject should be place in the discussion.

Reply: two sentences about the correlation between calculus and caries and between calculus and periodontal disease were added.

5) page 5, lines 1-3 - the sentence "Our study aims at investigating oral health in the coastal sample of Alghero by analysing a set of oral health indicators" stand all alone for itself. Please, put another sentence to make a better context for this one.

Reply: another sentence was added to make a better context.

6) page 6, lines 51-59 - why are you talking about foetuses since you're dealing with them in the paper at all? This part should be removed from the text as well as the belonging references.

Reply: the part about fetuses in the methods and references was removed.

7) page 8, lines 22-32 - again, you are talking about things that you're not dealing in this paper. The part containing the stable isotopes analysis doesn't have any value for this paper so it should be removed.

Reply: it would have been interesting to perform stable isotopic analysis to integrate the data about dental pathology to infer information on diet. Several papers of colleagues performed in similar works isotopic analysis. In our opinion it is important to declare the stable isotopic analyses were not performed because the faunal baseline was absent and not because the work is incomplete.

8) page 10-11 - when you are presenting the results of the analysis of carious lesions in adults it would be nice to have a comparison on carious frequency between different adult age categories as this is very important information. If possible, I'd like to see this information here.

Reply: The comparison between adult age categories was provided with a table and a graph which show the distribution by sex.

9) page 13, line 34 - you are talking about AMTL in isolated teeth?! How is that possible since the definition of an isolated tooth is a tooth outside of alveolus? This part has to be re-written.

Reply: the rate of ATML is derived not only from the remodeled alveoli but also from the isolated teeth should: if a tooth is present isolated is not lost ante-mortem. This was explained in the methods.

10) page 14, lines 43-48 - please, name the sites you're comparing Alghero with.

Reply: the sites used for comparison were mentioned.

11) page 14, line 60 and elsewhere in the discussion - using contemporaneous sites from different geographic positions is laudable, but a direct comparison with Lithuanian and Latvian samples might be far-fetched as these sites are located in a completely different ecological-climatic region resulting in different diet and therefore are not very good examples. You should focus more on Mediterranean sites from the same time period.

Reply: direct comparisons with Lithuanian and Latvian samples were removed.

12) page 19, lines 48-61; page 20, lines 1-12 - this paragraph is not very relevant for the study in question and I suggest to completely remove it.

Reply: in our opinion it is important to highlight that the population of Alghero was of mixed provenance and that therefore the skeletons from Alghero were probably not only Sardinians; however, the paragraph was heavily reduced.

13) page 23, lines 1-3 - the sentence "The subadults exhibit moderate rates of caries and is affected by calculus" doesn't make much sense. Please, re-word it. 
Reply: the sentence was rewritten.

14) I would like to see a map of Sardinia within the location of Alghero.

Reply: a map of Sardinia with the location of Alghero (figure 1) was added.

\section{Reviewer \#2:}

This seems like an interesting site and the results of an oral pathology assessment for the material would be of interest. However, there are some severe metholodological hurdles to be dealt with, specifically breaking the data into comparable statistics by normalising it by both observations possible and categories (like age) with different risk factors.

Reply: the statistics were normalized and categories like age were added.

It is unclear if the confusion over the text and the lack of referencing is due to translation errors, but as it currently stands the standard of definition of oral pathology and the review of literature for all subjects considered are unsuitable.

Reply: other references were added.

I have additional comments on the rest of the text, please find below.

Overall, the standard of English is good but must be improved for clarity.

Reply: the manuscript was revised by an English mother-tongue.

The convention for the period under discussion is I believe 'Early Modern' or 'Early Modern period' in English. Modern Age is not synonymous (and not defined).

Reply: Modern Age was eliminated and "Early Modern" or "Early Modern period" was used. Associated to a scarce oral hygiene should be retranslated if possible; I understand the meaning to be 'lack of oral hygiene', but I am not sue if this is correct.

Reply: "lack of oral hygiene" was used.

Citing only Hillson/ archaeological texts to describe oral pathology is inadequate referencing. This entire section is without sufficient references and does not display an understanding of oral pathlology. The (unreferenced) definition of periapical lesions is, for instance, incorrect. Hillson 2005 does not get this wrong, so it is very unclear where these definitions are coming from. Possibly the issues result from an error in translation?

Reply: other references were added, better definition of oral diseases and in particular of periapical lesions was provided, with references.

Why are foetuses included in a study of dental disease? Especially if they are not used in the sample studied?

Reply: The part about fetuses was removed.

Why the different indicators on different age groups? There is no justification given.

Reply: For dental diseases, the adult individuals were divided in three age ranges to fit the sample in homogenous and comparable sub-samples. This was explained in the text.

The scoring system for caries is poorly explained, one assumes it is as published in Minozzi and Canci?

Reply:the scoring system was better explained, as also reported in Minozzi and Canci (2015) The periapical lesion data is divided by observations possible versus observations made, why is this not done for the other categories?

Reply: the number of observations versus observables has been showed in all the tables for all categories, probably they were not sufficiently clear. We have improved the data presentation in the tables. There is no explanation for the biased sex ratio, even though work has been done on this. The authors are recommended to read work by DeWitte and colleagues on London plague samples.

Reply: a paragraph discussing the sex ratio in the plague cemetery of Alghero was added in the discussion. 
None of the data presented is meaningful without knowing the numbers of observations made. E.g. caries 'calculated' (how?) needs to be standardised by observations possible. Comparing individuals needs to be similarly normalised.

Reply: sorry, we cannot understand the reviewer comment: the data about caries were presented with the number of observables both for adults and subadults. At page 11, lines 4949, we have explained how the frequencies have been calculated and in all the tables, the number of observations has been reported for each dentoalveolar disease considered Nowhere is mention made of the age-related loss of teeth affecting the number of observations possible, which is a clear and well-known bias. This has to be normalised as well.

Reply:The comparison between adult age categories was provided with a table and graph which show the distribution of AMTL by age and sex.

I am utterly unconvinced that wear *increases* towards the posterior dentition; there has never been a population recorded with more advanced wear on their 3rd molars than on first. This is probably another translation error but it severely affects meaning.

Reply: a distinction between M1-M2 and M3 was added in the methods; M3 was in fact not considered in the evaluation of dental wear.

The authors argue sugar availability is the probable cause of dental disease but give no evidence for diet in Sardinia at the time until well into the discussion; starting off with only bioarchaeological case studies from elsewhere is insufficient.

Reply: the paragraph about the diet and alimentary resources in Alghero in the Early Modern period from historical sources was moved earlier in the discussion, putting it in the paragraph about caries.

Unreferenced assertions (e.g. about tooth extractions) are referenced much later in text; the referencing should occur in the first instance.

Reply: references were added to unreferenced assertions.

It aids understanding to contextualise claims prior to making them in the text; i.e. the diet of Sardinia should be part of the literature review as should the history of Sardinian tooth extraction rather than being introduced in the discussion. The discussion of Sardinian history should perhaps be kept to a relevant minimum however to make your argument.

Reply: the diet of Sardinia was moved earlier in the discussion, in the paragraph about caries. In our opinion the discussion of Sardinian history is important to understand the mixed ethnical composition and the social status of the population.

I don't think there is any argument for specific church communes to mix communities; unless in particular circumstance (usually heavily urbanised) they are usually reflective of a bounded geographic area and frequently reflect a mono-culture of the local group.

Reply: sorry, but we could not understand the reviewer comment.

You should credit the concept of frailty in plague to DeWitte in the first instance, rather than waiting for later.

Reply: the concept of frailty was moved at the beginning of the discussion.

\section{Editor:}

There were some technical problems with your submission. These are listed below for future reference.

Highlights. All five highlights are longer than the limit of 85 characters and spaces per highlight (see Guide for Authors - https://www.elsevier.com/journals/archives-of-oral-biology/00039969/guide-for-authors). Please shorten these in any resubmission. 
Reply: all five highlights were shortened.

Abstract. The Objective is not written as an objective

Reply: the objectives were rewritten.

Tables. The Tables contain vertical lines contrary to the instructions in the Guide for Authors. [I also wondered whether (some of) the Results might have been more accessible if they had been presented graphically rather than in tables.]

Reply: the vertical lines were removed and some graphs were added.

Authors' contributions. In order to be an author of a paper in the Archives of Oral Biology, an individual must meet the criteria for authorship set out by the International Committee of Medical Journal Editors. These are summarised in our Guide for Authors as making "substantial contributions to all of the following: (1) the conception and design of the study, or acquisition of data, or analysis and interpretation of data, (2) drafting the article or revising it critically for important intellectual content, (3) final approval of the version to be submitted." However, it is not entirely clear from the declarations of authors' contributions which accompanied your manuscript, whether all the named authors met all these criteria. Please note that if anyone contributes to an article but does not meet all three criteria for authorship listed above, he/she should be mentioned in an Acknowledgements section but must not be listed as an author.

Reply: the Authors' contributions were revised. All the three authors meet all three criteria for authorship. 


\author{
Dear Editor, \\ we revised the manuscript, according to the comments of the Editor. \\ Here in bold type a detailed list of the changes and the rebuttal against each point. In the \\ manuscript the changes are highlighted in yellow.
}

Editor comments:

Terminology. You state that you have substituted 'post-medieval' or '16th-century' for 'Early Modern'. However, you still use 'Early Modern' on one occasion (last sentence of the Introduction). In the interests of consistency, please revise here too.

Reply: Early Modern has been substituted with 16th century.

Scoring of calculus. You have added a statement "a score was made from the average of all observable teeth". However, the measurements were grades. How can you 'average' grades? Is averaging grades legitimate? Or do you mean that you took the median value (which certainly would be legitimate)? Please revise for clarity and justify if necessary.

Reply: we mean the median value; the sentence has been corrected.

Figure 1. Are there any copyright issues in respect of the map which you have added at the suggestion of the Reviewer? Please check our Guide for Authors

(https://www.elsevier.com/journals/archives-of-oral-biology/0003-9969/guide-for-authors) and either re-assure us in writing that there is no copyright issue, or provide the necessary documentation if there is a copyright issue.

Reply: We selected another map which has no copyright issues. 
- High frequency of caries was observed both in males and females

- Periodontal disease, ATML and calculus were diffuse

- Abscesses were not frequent and calculus was moderate

- The diet was rich in carbohydrates and was associated to lack of oral hygiene

- The patterns observed in Alghero fit with the data from other Modern Age samples 

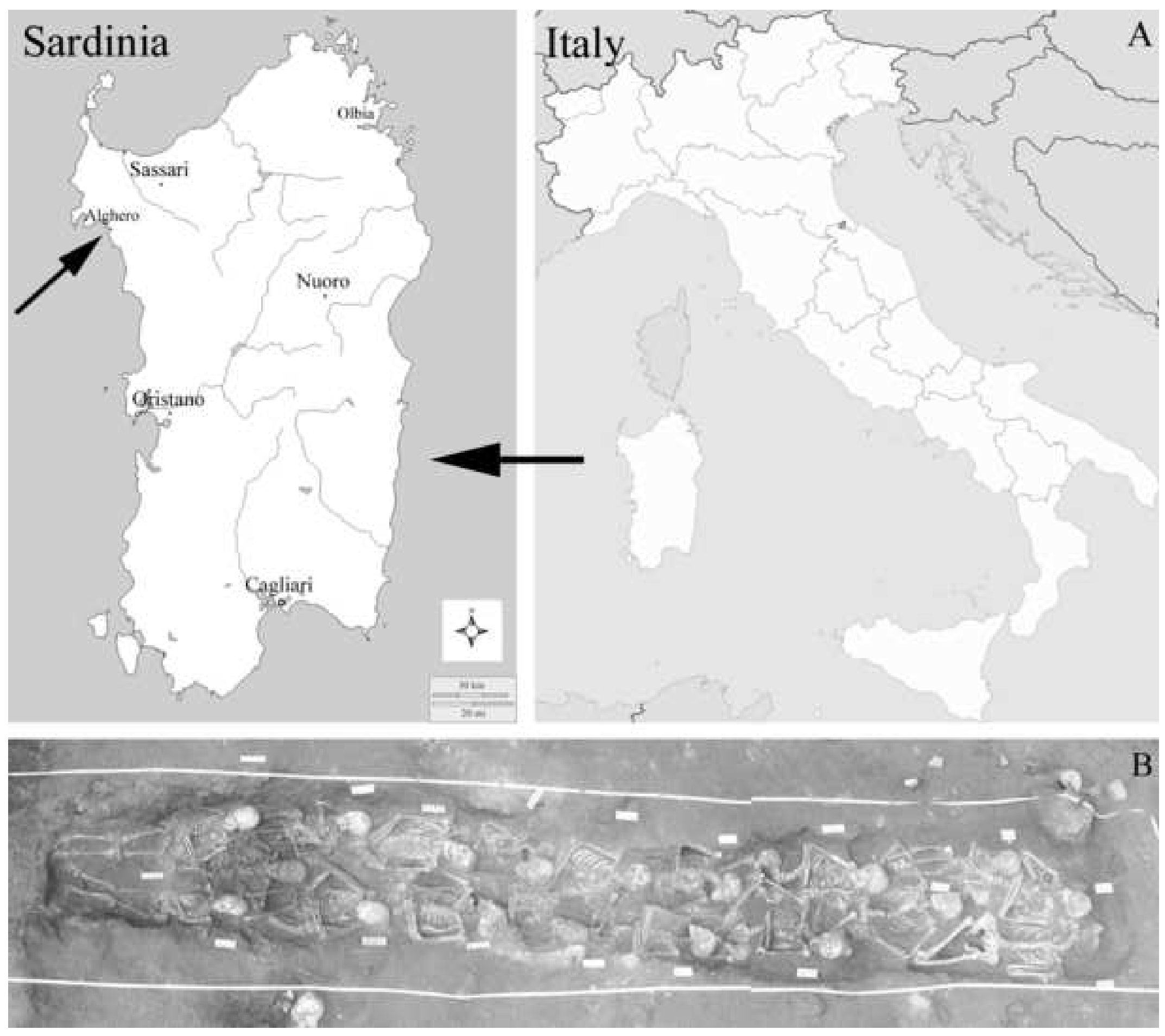


\section{Distribution of caries by tooth type}

40

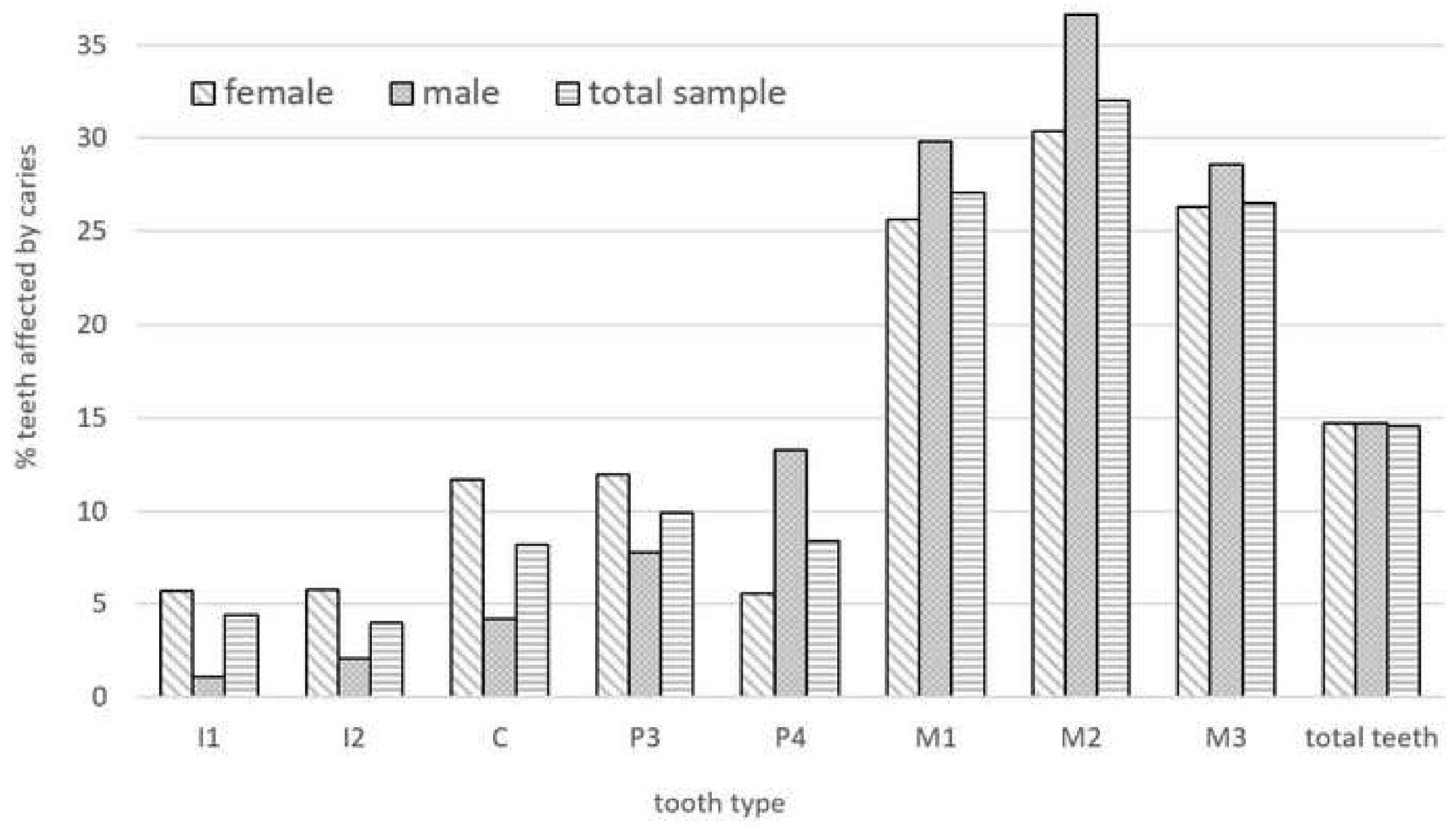




\section{Distribution of caries by sex and age}

25
$\square$ female $\square$ male $\quad$ Gtotal sample

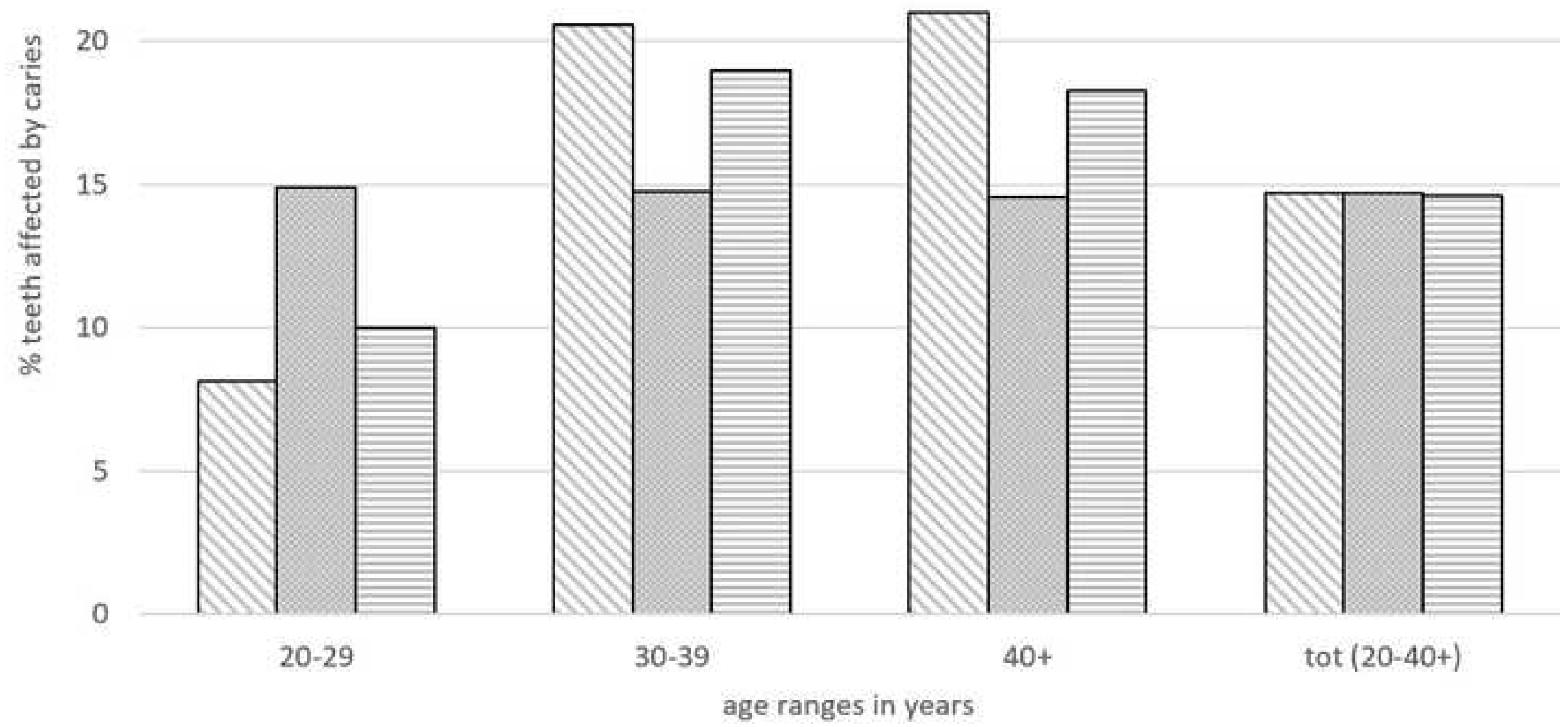




\section{Distribution of AMTL by sex and age}

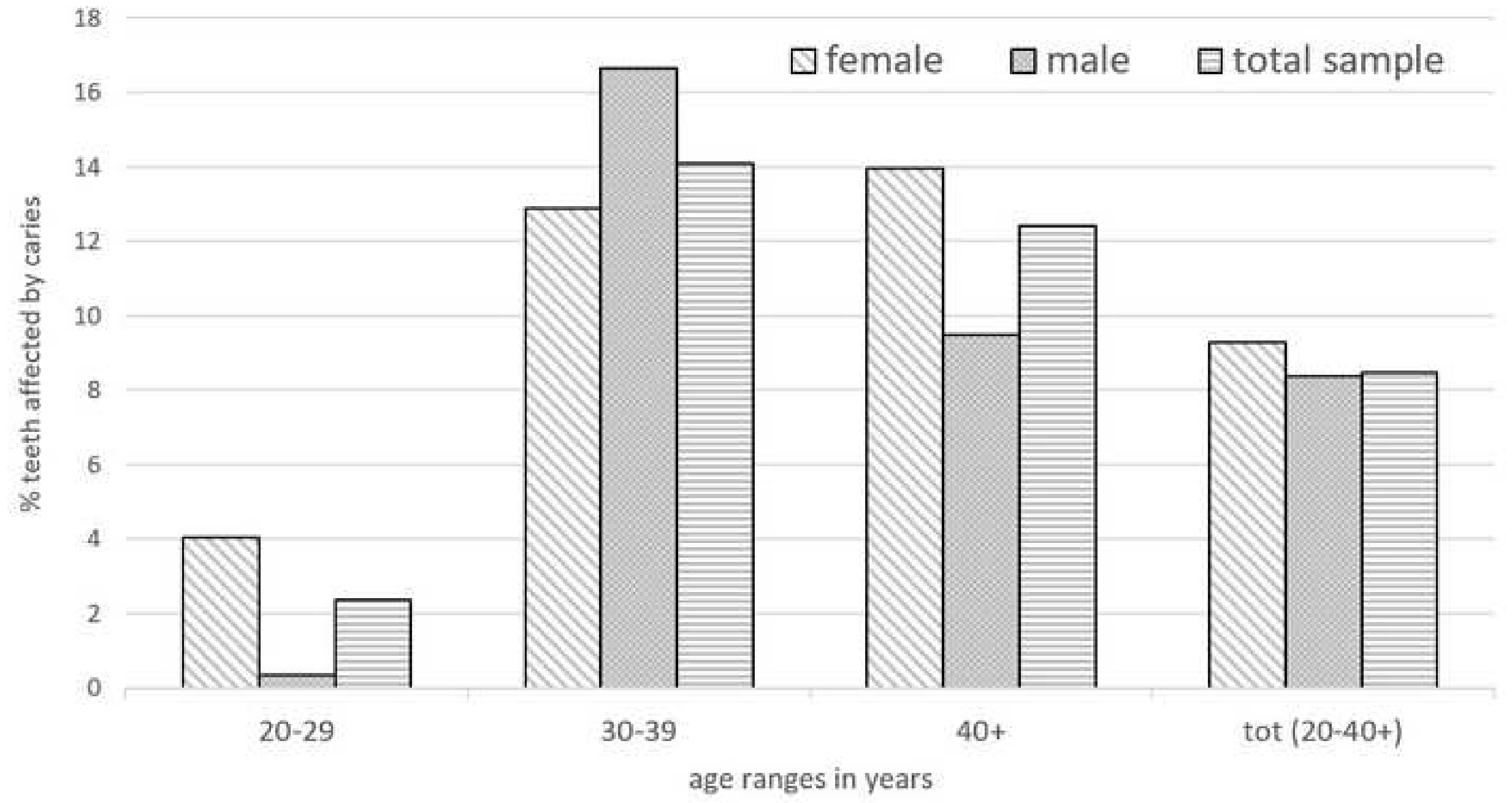




\begin{tabular}{lccccc} 
Age category & M & F & ND & Total & \% \\
\hline Early childhood (2-6) & - & - & 17 & 17 & 10,6 \\
Late childhood (7-12) & - & - & 39 & 39 & 24,4 \\
Adolescence (13-19) & - & - & 23 & 23 & 14,4 \\
Young adulthood (20-25) & 6 & 16 & 2 & 24 & 15,0 \\
Middle adulthood (26-35) & 12 & 15 & 2 & 29 & 18,1 \\
Mature adulthood (36-45) & 10 & 13 & 1 & 24 & 15,0 \\
Old/senile adulthood (46-55) & 2 & 2 & 0 & 4 & 2,5 \\
\hline Total & 30 & 46 & 84 & 160 & 100 \\
\hline
\end{tabular}

Table 1. Demographic distribution of the individuals analyzed for dental health $(\mathrm{N}=160)$ from the plague cemetery of Alghero 


\begin{tabular}{ccccccccccccc} 
& \multicolumn{3}{c}{ Females } & \multicolumn{3}{c}{ Males } & \multicolumn{4}{c}{$\begin{array}{c}\text { Not } \\
\text { determinable }\end{array}$} & \multicolumn{3}{c}{ Total } \\
\hline Tooth & N & Obs & \% & N & Obs & \% & N & Obs & \% & N & Obs & \% \\
\hline I1 & 8 & 140 & 5.7 & 1 & 89 & 1.1 & 2 & 20 & 10 & 11 & 249 & 4.4 \\
I2 & 8 & 138 & 5.8 & 2 & 94 & 2.1 & 0 & 18 & 0 & 10 & 250 & 4.0 \\
C & 18 & 154 & 11,7 & 4 & 96 & 4.2 & 0 & 17 & 0 & 22 & 267 & 8.2 \\
P3 & 17 & 142 & 12.0 & 7 & 90 & 7.8 & 1 & 20 & 5 & 25 & 252 & 9.9 \\
P4 & 8 & 143 & 5.6 & 12 & 90 & 13.3 & 1 & 18 & 5.6 & 21 & 251 & 8.4 \\
M1 & 33 & 129 & 25.6 & 25 & 84 & 29.8 & 6 & 23 & 26 & 64 & 236 & 27.1 \\
M2 & 42 & 138 & 30.4 & 34 & 93 & 36.6 & 7 & 28 & 25 & 83 & 259 & 32.0 \\
M3 & 25 & 95 & 26.3 & 18 & 63 & 28.6 & 5 & 23 & 2.2 & 48 & 181 & 26.5 \\
\hline Total teeth & 159 & 1079 & $\mathbf{1 4 . 7}$ & 103 & 699 & $\mathbf{1 4 . 7}$ & 22 & 167 & $\mathbf{1 3 . 2}$ & 284 & 1945 & $\mathbf{1 4 . 6}$ \\
\hline Individuals* & 36 & 45 & $\mathbf{8 0 . 0}$ & 23 & 29 & $\mathbf{7 9 . 3}$ & 7 & 9 & $\mathbf{7 7 . 8}$ & 66 & 83 & $\mathbf{7 9 . 5}$ \\
\hline
\end{tabular}

Table 2. Distribution of carious teeth by sex and tooth type in adult individuals.

Legend: $\mathrm{N}=$ number of teeth/individuals affected by caries; Obs = observable teeth; $\mathrm{I}=$ incisor; $\mathrm{C}=$ canine; $\mathrm{PM}=$ premolar; $\mathrm{M}=$ molar. ${ }^{*}$ Individuals with at least 14 teeth not affected are considered observable 


\begin{tabular}{lccc} 
& Carious teeth & Observables & $\%$ \\
\hline Females & & & \\
\hline $20-29$ & 42 & 517 & 8.1 \\
$30-39$ & 51 & 248 & 20.6 \\
$40+$ & 66 & 314 & 21.0 \\
Tot & 159 & 1079 & 14.7 \\
\hline Males & & & \\
\hline $20-29$ & 37 & 248 & 14.9 \\
$30-39$ & 28 & 190 & 14.7 \\
$40+$ & 38 & 261 & 14.6 \\
Tot & 103 & 699 & 14.7 \\
\hline Not determinable & & & \\
\hline $20-29$ & 12 & 144 & 8.3 \\
$30-39$ & 8 & 20 & 40.0 \\
$40+$ & 2 & 3 & 66.7 \\
Tot & 22 & 167 & 13.2 \\
\hline Total sample & & & \\
\hline $20-29$ & 91 & 909 & 10.0 \\
$30-39$ & 87 & 458 & 19.0 \\
$40+$ & 106 & 578 & 18.3 \\
Tot & 284 & 1945 & 14.6 \\
\hline
\end{tabular}

Table 3.Distribution of caries by sex in age ranges in adult individuals. 


\begin{tabular}{lllllllll} 
Localisation & $\mathbf{F}$ & $\mathbf{\%}$ & $\mathbf{M}$ & $\mathbf{\%}$ & ND & $\mathbf{\%}$ & Total & \% \\
\hline Crown & 135 & 67.5 & 102 & 73.4 & 18 & 66.7 & 255 & 69.7 \\
Neck & 60 & 30 & 27 & 19.4 & 9 & 33.3 & 96 & 26.2 \\
Root & 5 & 2.5 & 10 & 7.2 & 0 & 0 & 15 & 4.1 \\
Total caries & 200 & & 139 & & 27 & & 366 & \\
\hline Surface & $\mathbf{F}$ & $\mathbf{\%}$ & $\mathbf{M}$ & $\mathbf{\%}$ & $\mathbf{N D}$ & $\mathbf{\%}$ & Total & $\mathbf{\%}$ \\
Occlusal & 59 & 33.9 & 42 & 33.1 & 11 & 42.3 & 112 & 34.3 \\
Buccal & 23 & 13.2 & 21 & 16.5 & 3 & 11.6 & 47 & 14.4 \\
Lingual & 4 & 2.3 & 2 & 1.6 & 1 & 3.8 & 7 & 2.1 \\
Interproximal & 88 & 50.6 & 62 & 48.8 & 11 & 42.3 & 161 & 49.2 \\
Total caries & 174 & & 127 & & 26 & & 327 & \\
\hline Severity & $\mathbf{F}$ & $\mathbf{\%}$ & $\mathbf{M}$ & $\mathbf{\%}$ & $\mathbf{N D}$ & $\mathbf{\%}$ & Total & $\mathbf{\%}$ \\
Grade 1 & 83 & 41.5 & 59 & 42.4 & 13 & 48.2 & 155 & 42.3 \\
Grade 2 & 46 & 23.0 & 36 & 25.9 & 3 & 11.1 & 85 & 23.2 \\
Grade 3 & 43 & 21.5 & 31 & 22.3 & 9 & 33.3 & 83 & 22.7 \\
Grade 4 & 26 & 13.0 & 13 & 9.4 & 2 & 7.4 & 43 & 11.7 \\
Total caries & 200 & & 139 & & 27 & & 366 & \\
\hline
\end{tabular}

Table 4. Localisation and severity of the caries in females, males and individuals of undeterminable $\operatorname{sex}$ 


\begin{tabular}{lccc} 
Age range & Individuals affected & Individuals observable & \% on individuals \\
\hline 2-6 years & 3 & 8 & 37.5 \\
7-12 years & 22 & 28 & 78.6 \\
13-19 years & 12 & 17 & 70.6 \\
Total & 37 & 53 & 69.8 \\
\hline Age range & Teeth affected & Teeth observable & \% on teeth \\
\hline 2-6 years & 9 & 132 & 6.8 \\
7-12 years & 68 & 615 & 11.1 \\
13-19 years & 34 & 432 & 7.9 \\
Total & 111 & 1179 & 9.4 \\
\hline Deciduous & 66 & 311 & 21.2 \\
\hline Permanent & 45 & 868 & 5.2 \\
\hline
\end{tabular}

Table 5. Distribution of caries in age ranges in subadults by individual and by tooth 


\begin{tabular}{lllllll} 
Position & Deciduous & \% & Permanent & \% & Total & \% \\
\hline Crown & 57 & 80.3 & 61 & 92.4 & 118 & 86.1 \\
Neck & 13 & 18.3 & 5 & 7.6 & 18 & 13.2 \\
Root & 1 & 1.4 & 0 & 0 & 1 & 0.7 \\
Total observables & 71 & & 66 & & 137 & \\
\hline Surface & Deciduous & \% & Permanent & \% & Total & \% \\
\hline Occlusal & 7 & 10.1 & 50 & 75.8 & 57 & 42.2 \\
Buccal & 2 & 2.9 & 4 & 6.1 & 6 & 4.4 \\
Lingual & 0 & 0 & 2 & 3.0 & 2 & 1.5 \\
Interproximal & 60 & 87.0 & 10 & 15.1 & 70 & 51.9 \\
Total observables & 69 & & 66 & & 135 & \\
\hline Severity & Deciduous & $\%$ & Permanent & \% & Total & \% \\
\hline Grade 1 & 21 & 29.6 & 53 & 80.3 & 74 & 54.0 \\
Grade 2 & 23 & 32.4 & 6 & 9.1 & 29 & 21.2 \\
Grade 3 & 24 & 33.8 & 7 & 10.6 & 31 & 22.6 \\
Grade 4 & 3 & 4.2 & 0 & 0 & 3 & 2.2 \\
Total observables & 71 & & 66 & & 137 & \\
\hline
\end{tabular}

Table 6. Localisation and severity of the caries in deciduous and permanent teeth in subadults 
Degrees of severity

\begin{tabular}{lcccccc}
\hline Females & $\mathbf{0}$ & $\mathbf{1}$ & $\mathbf{2}$ & $\mathbf{3}$ & $\begin{array}{c}\text { Individual } \\
\text { observables }\end{array}$ & \% grades 2-3 \\
\hline 20-29 years & 5 & 10 & 3 & 1 & 19 & $\mathbf{2 1 . 1}$ \\
$30-39$ years & 1 & 2 & 5 & 2 & 10 & $\mathbf{7 0 . 0}$ \\
$40+$ & 0 & 4 & 8 & 1 & 13 & $\mathbf{6 9 . 2}$ \\
Total & 6 & 16 & 16 & 4 & 42 & $\mathbf{4 7 . 6}$ \\
\hline Males & & & & & & \\
\hline $20-29$ years & 2 & 4 & 1 & 1 & 8 & $\mathbf{2 5 . 0}$ \\
$30-39$ years & 0 & 1 & 6 & 1 & 8 & $\mathbf{8 7 . 5}$ \\
40+ & 0 & 4 & 4 & 3 & 11 & $\mathbf{6 3 . 6}$ \\
Total & 2 & 9 & 11 & 4 & 26 & $\mathbf{5 7 . 7}$ \\
\hline No determinable & & & & & & $\mathbf{0}$ \\
\hline 20-29 years & 2 & 0 & 0 & 0 & 2 & $\mathbf{1 0 0}$ \\
30-39 years & 0 & 0 & 1 & 0 & 1 & $\mathbf{0}$ \\
40+ & 0 & 0 & 0 & 0 & 0 & $\mathbf{3 3 . 3}$ \\
Total & 2 & 0 & 1 & 0 & 3 & \\
\hline All the sample & 10 & 25 & 28 & 8 & 71 & $\mathbf{5 0 . 7}$ \\
\hline
\end{tabular}

Table 7. Distribution of three degrees of severity of alveolar resorption by sex and age ranges 


\begin{tabular}{lcccc} 
& F & M & ND & TOT. \\
\hline Abscesses & & & & \\
\hline N. abscesses & 5 & 10 & 0 & 15 \\
Observables for abscesses (2+4) & 938 & 590 & 40 & 1568 \\
\hline \% abscesses on alveoli & $\mathbf{0 . 5}$ & $\mathbf{1 . 7}$ & $\mathbf{0}$ & $\mathbf{1 . 0}$ \\
\hline N. individuals with abscesses & 4 & 6 & 0 & 10 \\
Observables & 34 & 22 & 1 & 57 \\
\hline \% abscesses on individuals & $\mathbf{1 1 . 8}$ & $\mathbf{2 7 . 3}$ & 0 & $\mathbf{1 7 . 5}$ \\
\hline & & & & \\
\hline AMTL & & & & \\
\hline 1 Teeth lost during life (AMTL) & 120 & 70 & 5 & 195 \\
2 Teeth lost after death & 97 & 61 & 10 & 168 \\
3 Teeth isolated & 230 & 170 & 140 & 540 \\
4 Teeth in situ & 841 & 529 & 30 & 1400 \\
3+4 = tot. teeth & 1071 & 699 & 170 & 1940 \\
1+2+3+4 observables & 1288 & 830 & 185 & 2303 \\
\hline \% AMTL on alveoli & $\mathbf{9 . 3}$ & $\mathbf{8 . 4}$ & $\mathbf{2 . 7}$ & $\mathbf{8 . 5}$ \\
\hline Individuals with AMTL & 23 & 17 & 2 & 42 \\
Observables & 43 & 29 & 6 & 78 \\
\hline \% AMTL on individuals & $\mathbf{5 3 . 5}$ & $\mathbf{5 8 . 6}$ & $\mathbf{3 3 . 3}$ & $\mathbf{5 3 . 8}$ \\
& & & &
\end{tabular}

Table 8 . Frequencies by alveoli and by individuals of abscesses and teeth lost during life (AMTL) 
AMTL observables \% AMTL

\begin{tabular}{lccc}
\hline Females & & & \\
\hline $20-29$ & 23 & 567 & 4.1 \\
$30-39$ & 45 & 349 & 12.9 \\
$40+$ & 52 & 372 & 14.0 \\
Total & 120 & 1288 & 9.3 \\
\hline Males & & & \\
\hline $20-29$ & 1 & 285 & 0.4 \\
$30-39$ & 40 & 240 & 16.7 \\
$40+$ & 29 & 305 & 9.5 \\
Total & 70 & 830 & 8.4 \\
\hline No determinables & & & \\
\hline $20-29$ & 0 & 157 & 0.0 \\
$30-39$ & 1 & 21 & 4.8 \\
$40+$ & 4 & 7 & 57.1 \\
Total & 5 & 185 & 2.7 \\
\hline Total & & & \\
\hline $20-29$ & 24 & 1009 & 2.4 \\
$30-39$ & 86 & 610 & 14.1 \\
$40+$ & 85 & 684 & 12.4 \\
Total & 195 & 2303 & 8.5 \\
\hline
\end{tabular}

Table 9. Distribution of AMTL by age ranges in adults (\% on alveoli plus isolated teeth) 


\begin{tabular}{lccccc} 
Severity of calculus & F & M & ND & TOT & SUBADULTS \\
\hline Absent & 3 & 1 & 4 & 8 & 22 \\
Mild & 22 & 13 & 3 & 38 & 21 \\
Strong & 20 & 16 & 2 & 38 & 3 \\
Individual observables & 45 & 30 & 9 & 84 & 46 \\
\hline$\%$ mild & 48.9 & 43.3 & 33.3 & 45.2 & 45.7 \\
$\%$ strong & 44.4 & 53.3 & 22.2 & 45.2 & 6.5 \\
\% mild + strong & 93.3 & 96.7 & 55.6 & 90.5 & 52.2 \\
\hline
\end{tabular}

Table 10. Distribution and severity of calculus by individual, in adults and subadults. 
Average wear score

\begin{tabular}{lccccc}
\hline & n. individuals & anterior teeth & premolars & molars & total \\
\hline Females & & & & & \\
\hline $20-29$ & 19 & 2.6 & 2.8 & 2.8 & 2.7 \\
$30-39$ & 13 & 3.5 & 4.0 & 4.1 & 3.8 \\
$40+$ & 14 & 4.6 & 4.9 & 5.4 & 5.0 \\
\hline Males & & & & & \\
\hline $20-29$ & 10 & 3.5 & 3.4 & 3.5 & 3.4 \\
$30-39$ & 8 & 4.1 & 4.4 & 4.2 & 4.2 \\
$40+$ & 12 & 5.0 & 5.2 & 5.5 & 5.2 \\
\hline Total & & & & & \\
\hline $20-29$ & 29 & 2.9 & 3.0 & 3.0 & 3.0 \\
$30-39$ & 21 & 3.8 & 4.2 & 4.1 & 4.0 \\
$40+$ & 26 & 4.8 & 5.0 & 5.5 & 5.1 \\
\hline
\end{tabular}

Table 11. Average wear score for males and females calculated for each tooth category. The mean value has been calculated for upper and lower teeth together 


\begin{tabular}{lcccc} 
Tooth wear & F & \%F & M & \% M \\
\hline Grades 1-3 & 19 & 42.2 & 8 & 26.6 \\
Grades 4-5 & 22 & 48.9 & 17 & 56.7 \\
Grades 6-8 & 4 & 8.9 & 5 & 16.7 \\
Total observed & 45 & & 30 & \\
\hline
\end{tabular}

Table 12. Frequency of individuals with different grades of tooth wear in molars 


\section{Dental health in adults and subadults from the $16^{\text {th }}$-century plague cemetery of}

\section{Alghero (Sardinia, Italy)}

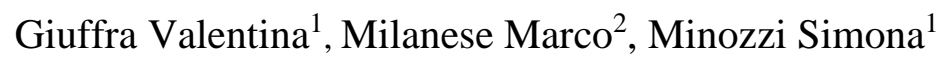

${ }^{I}$ Division of Paleopathology, Department of Translational Research and New Technologies in Medicine and Surgery, University of Pisa, Via Roma 57, 56126 Pisa, Italy

${ }^{2}$ Department of History, Human Sciences and Education, University of Sassari, Via Maurizio Zanfarino 62, 07100 Sassari, Italy

\section{Corresponding author:}

Valentina Giuffra

Division of Paleopathology, Department of Translational Research and New Technologies in Medicine and Surgery, Via Roma 57, 56126 Pisa, Italy; E-mail: valentina.giuffra@unipi.it Tel.: 0039050 992894; fax: 0039050992706

Running title: Dental health in $16^{\text {th }}$-century Alghero

Key words: oral pathologies, caries, abscesses, calculus, tooth wear, paleopathology

Declarations of interest: none 


\section{Abstract}

Objective: The aim of this study is to examine a set of dental health indicators, including caries, periodontal disease, abscesses, ante-mortem tooth loss, calculus, and tooth wear of a $16^{\text {th }}$-century population from the city of Alghero, Sardinia (Italy), in order to evaluate the state of dental health and the diet.

Design: The cemetery is referable to the plague outbreak that ravaged the city in 1582-1583. A total of 160 individuals (81 adults and 79 subadults) were suitable for dental examination.

Results: The oral conditions of the urban population of Alghero are characterised by high frequency of carious lesions, periodontal disease, ante mortem tooth loss, and calculus, but a low prevalence of abscesses and moderate tooth wear are recorded. In general, no statistically significant sexual differences are observed, suggesting a uniform scenario for diet access and oral health. The subadult subsample shows moderate rates of caries and is affected by calculus. The results suggest that the diet was rich in soft and refined food, with a prevalence of carbohydrates and cariogenic aliments; the effects of the diet are associated with a lack of oral hygiene.

Conclusions: The patterns of dental health observed in the Alghero population fit with the data observed in other Modern Age samples, reflecting increased prevalence of dentoalveolar diseases resulting from a less abrasive diet and an increase in carbohydrate consumption, as documented during the transition from the Middle Ages to the Modern period. 


\section{Introduction}

Teeth represent the hardest tissue of the human body, resisting to chemical and physical destruction better than any other skeletal element. Therefore, dental diseases provide essential information on the health status of past populations over different periods of time. Such conditions can be influenced by a combination of many factors, which reflect differences in diet, alimentary behaviour, physiological and hormonal aspects, access to medical care, and differences in social roles (Hillson, 1996).

In this study the following dental diseases will be evaluated: caries, periodontal disease, abscesses, ante-mortem tooth loss (AMTL), calculus, and tooth wear; these oral health indicators were selected as they are largely related to diet and dental hygiene.

Caries is a degenerative pathology caused by the demineralization of dental tissues due to the acidic oral environment produced by some species of bacteria normally living in the microbial flora (Moore \& Corbett, 1983; Caselitz, 1998). The consumption of simple carbohydrates and sugars, poor oral hygiene and periodontal disease may favour the proliferation of cariogenic bacteria and the acidic attack of enamel and dentine. Caries originates from the tooth surface and, over time, it penetrates the dental pulp facilitating the spread of bacteria within the bone tissues. This process typically causes infections, with the consequent presence of abscesses leading to tooth loss (Hillson, 2005). Caries is the result of the interdependence of oral microbial load, dietary habits and oral care, and also of host factors such as quantitative and qualitative salivary flow and genetic predisposition (Rathhe \& Sapra, 2019). In particular, dental caries is related to the consumption of carbohydrates and sweet foods and can provide useful information on dietary reconstruction (Hillson, 2005; Larsen, Shavit \& Griffin, 1991).

Periodontal disease is a chronic condition characterized by inflammation and destruction of the periodontal tissues, including the alveolar bone, and results in the atrophy of the alveolar crest and in alveolar resorption. It can be caused by a variety of physiological or functional problems, but the principal causes are pathogenic infectious agents accumulated in the dental plaque on account of poor oral hygiene (Gasner \& Schure, 2020; Strohm \& Kurt, 1998). Alongside the presence of bacteria, 
host susceptibility also plays a role in the occurrence of periodontal disease (Stabholz, Soskolne \& Shapira, 2010). Inflammation causes retraction of the gingiva with dental root exposure following the onset of alveolar pockets, which can lead to infections, abscesses, resorption of the alveolar bone, and eventually to tooth loss (Cripps, 1984; Larsen, Shavit \& Griffin, 1991; Hillson, 2005). Resorption of the alveolar margin can help to diagnose periodontal disease in human skeletal remains. Periodontal disease generally showed higher rates in populations consuming soft and processed foods; in particular, high carbohydrate intake favors the expansion of dental plaque and pathogenic bacteria, promoting periodontal disease (Huynh, Verneau, Levasseur, Drancourt \& Aboudharam, 2016).

To discriminate among different factors that favor tooth decay and periodontal diseases is not easy, since they are influenced by biological, environmental, genetic, cultural, and even behavioral factors, but alimentary habits play a decisive role. In this regard, caries and periodontal disease are evaluated, in this research, as potential indicators of carbohydrate consumption in the diet.

An abscess is a pulpal inflammation that spreads through the apical foramen to the jawbone and that results in acute localized periapical infection (Miller et al. 1995). The infection can affect the pulp through a carious lesion, dental trauma or crown fracture; severe attrition, especially when there is exposure of the pulp cavity, can also lead to infection (Sanders \& Houck, 2019). An abscess can be recognized in skeletal remains by the presence of a roundish cavity in the periapical region of the tooth or by a fistula in the mandibular or maxillary bone (Hillson, 2005). The presence of this bone lesion is due to a chronic evolution of suppurative acute inflammation inducing an osteolytic process in the jawbone (Alt, Turp \& Wachter, 1998). Chronic periapical infections could represent areas of potential danger to health, as in the pre-antibiotic era the diffusion of the bacteria through the bloodstream could induce a septicaemia with lethal effects.

Caries, periodontal disease and abscesses can cause AMTL (Hillson, 2005). A significant increase in AMTL was generally observed at increasing age (Fujita et al., 2013). The frequency of tooth loss can also be related to the medical and dental practices of tooth extraction. AMTL was included in this study to provide an indicator of overall dental health. 
Dental calculus is caused by mineralization of the bacterial plaque and develops in an alkaline environment (Akcali \& Lang, 2018). There is a close relation between dental hygiene and occurrence of calculus, and therefore its presence can provide information on the oral bacterial flora (microbiome), on nutrition and on the hygienic conditions of past populations (Hillson, 2005). Studies conducted on past populations evidenced that calculus deposits tend to increase in agricultural economies, owing to a diet based mainly on soft and cooked carbohydrates (Huynh, Verneau, Levasseur, Drancourt \& Aboudharam, 2016). In this study, the presence and severity of calculus deposits are considered in relation to caries and periodontal disease.

Finally, occlusal tooth wear is the gradual loss of tooth substances, namely enamel and possibly dentine, as a result of natural mastication due to a combination of attrition (inter-tooth friction) and abrasion (friction from food) (Kaidonis, 2008). Patterns of tooth wear can provide information on the types of foods consumed and on food processing techniques; in general, hard and abrasive food results in more occlusal dental wear, while soft, grit-free food results in lower rates of wear (Hillson, 1996; Larsen, 1997). Wear is also important to interpret caries frequencies, because the loss of occlusal surfaces can obliterate caries at initial stages, but it can also increase the risk of abscesses and AMTL as a consequence of pulp exposure (Hillson, 1996).

Our study aims to investigate oral health in the Italian coastal sample of Alghero (Sassari, Sardinia, fig.1A) by analysing a set of oral health indicators. In particular, caries, periodontal disease, abscesses, AMTL, calculus, and tooth wear were evaluated in the adult population, and caries and calculus also in the subadult subsample, so as to infer information about the diet, oral hygiene and dental pathologies of a Sardinian population of the $16^{\text {th }}$ century.

\section{Materials and methods}

In 2008-2009 archaeological excavations undertaken by the University of Sassari in the courtyard of the former Jesuits' College in San Michele - Lo Quarter in the city of Alghero, Sardinia (Fig.1 A), brought to light a large burial area, used continuously from the end of the $13^{\text {th }}$ century to the 
beginning of the $17^{\text {th }}$ century (Milanese, 2010; Milanese, 2013). In Medieval times the area was occupied by the complex of the Church of San Michele, which included the cemetery. Five welldistinguished chronological phases were identified within the site, some of which can be attributed to the Medieval period and others to the Modern era (Milanese, 2010).

The area corresponding to the courtyard of the Jesuit college revealed a particular burial typology, consisting in 16 long and narrow trenches, in which the remains of 2 to 30 individuals were buried together and simultaneously, for a total of 184 individuals. The deceased were disposed in two rows, with the head placed on the pelvis of the previously inhumed person (Fig.1B). The trenches reflect a catastrophic burial modality, referable to an epidemic episode, in which a number of corpses needed to be buried in a short lapse of time. Archaeological elements, based on the analysis of the pottery and objects associated with the skeletal remains, allowed to date the trenches back to the second half of the $16^{\text {th }}$ century (Milanese, 2010). For this period the written sources document a plague episode that ravaged the town of Alghero in 1582-1583. The estimation of this epidemic wave appears to be disastrous: the sources report about six thousand deaths, and one hundred and fifty survivors for the city of Alghero (Manconi, 1994). Therefore, the trenches of Alghero can be referred to the plague outbreak of 1582-1583. The burial typology of the trenches observed in Alghero is a unique finding in the Mediterranean basin, as attested only in $18^{\text {th }}$ century France (Bizot, Castex, Reynaud, \& Signoli, 2005; Signoli, Chausserie-Lapree, \& Dutour, 1997; Signoli, Chevé, Adalian, Boetsch, \& Dutour, 2007; Tzortzis \& Signoli, 2009).

The living conditions of the urban population were certainly richer than those of the rural population in most regions of Sardinia. The majority of people in the countryside were peasants working in agriculture and in husbandry, but in the economy of the city of Alghero, which assumed the role of main harbor of northern Sardinia, the merchants represented the leading social class, especially for maritime commercial contacts mainly with Catalonia (Milanese, 2015; Sorgia, 1982).

The nobility descending from the ancient Catalan families were in decline but still present in the aristocracy of the town. The clergy also played an important role in society, since at least seven 
churches were present in Alghero. The middle social class was represented by livestock owners, apothecaries, shopkeepers and some artisans, whereas the lower classes included the population of shepherds, farmhands, peasants, craftsmen, fishermen and servants (Budruni, 2010). Therefore, Alghero was a crossroads of cultures, crafts and social statuses and the cemetery of San Michele probably reflects this mixture, since the emergency dictated by the epidemic left no time to select different burial areas for different social groups.

The plague cemetery of Alghero represents an interesting biological archive of the population of the town in the second half of the $16^{\text {th }}$ century AD. In this paper the dental health of the individuals exhumed from the plague cemetery of Algheri was analysed, considering adult and subadult individuals.

Sex determination of the adult individuals was performed on the basis of the morphological features of the skull and pelvis (Buikstra \& Ubelaker, 1994; Ferembach, Schwidetzky, \& Stloukal, 1980); if a few characters of the skull and pelvis were observable, metrical data obtained from postcranial bones were used when possible (Afrianty, 2013; Berrizbeitia, 1989; Krogman \& Iscan, 1986; Silva, 1995).

The age at death of adult individuals was determined on the basis of dental wear (Lovejoy, 1985), pubic symphysis surface morphology (Brooks \& Suchey, 1990), auricular surface of ilium morphology (Lovejoy, Meindl, Pryzbeck, \& Mensforth, 1985), and sternal rib-end modification (İşcan, Loth, \& Wright, 1984; İşcan \& Loth, 1985). The age at death of the subadult individuals was assessed by measurement of long-bone diaphyses (Scheuer \& Black, 2000; Stloukal \& Hanakova, 1978), by stage of fusion between diaphyses and epiphyses (Schaefer, Black, \& Scheuer, 2009; Scheuer \& Black, 2000), and by stages of development and dental eruption (Stermer Beyer-Olsen and Risnes, 1994; Ubelaker, 1989). The age categories used in this work are those proposed by Iscan \& Steyn (2013).

Six parameters were examined, namely dental caries, periodontal disease, abscesses, AMTL, calculus, and tooth wear. Dental caries and calculus were recorded both on adults and subadults, the 
other indicators only on adults, as no evidence of periodontal disease, abscesses, AMTL, and tooth wear were found in children. Caries was evaluated macroscopically under a bright light with the help of a dental probe and was considered only if there was cavitation. The lesions were recorded according to 4 grades of severity as suggested by Minozzi \& Canci (2015). Grade 1: small and superficial cavitation mostly affecting the enamel and only partially reaching the dentine; grade 2 : larger lesion affecting the dentine; grade 3: deeper lesion with involvement of the dental pulp; grade 4: complete destruction of the crown. The carious lesions were observed together with their location: crown, neck, and root, and side of the affected tooth: occlusal, buccal, lingual, and interproximal.

Periodontal disease, here also named alveolar resorption, was recorded by analyzing the resorption of the alveolar margin of the maxilla and of the mandible, based on the distance of the alveolar margin from the cemento-enamel junction, using four grades $(0=$ absence; $1=$ slight, $2-3 \mathrm{~mm} ; 2=$ moderate, 3-5 mm; 3 = severe, $>5 \mathrm{~mm}$ ) indicated by Brothwell (1981). The maxilla and the mandible were considered together for data processing; in those cases in which the severity of alveolar resorption between the maxilla and the mandible was different, the individual was assigned the highest value. Recording of the abscesses, here also named periapical lesions, was based on the presence of a drainage channel in the alveolar bone or of a roundish cavity at the periapical region of the affected tooth.

AMTL was recorded by alveolus; a tooth was considered as lost ante-mortem if the socket showed signs of partial or complete remodelling. Teeth found in situ despite destruction or loss of associated jaw were counted as observable; therefore, the frequency was calculated as the number of AMTLs divided by the number of observable alveoli plus the isolated teeth. Isolated teeth were included in the total number of observable alveoli because they were all attributed to each mandible or maxilla. Therefore, a tooth present and in isolation was not considered lost ante-mortem, even if the alveolar bone was missing.

The distribution of dentoalveolar diseases was calculated per element (tooth/alveolus) and per individual: the frequencies were calculated as the number of affected teeth/alveoli divided by the 
number of observable teeth/alveoli, as well as the number of affected individuals divided by the number of observable individuals. An individual was considered observable if at least 14 teeth/alveoli were preserved.

As for dental calculus, a score was made from the median value of all observable teeth, according to Brothwell's method (1981), which considered three grades: slight, medium and considerable. In this work the grades medium and considerable were merged so as to obtain a subdivision into mild and strong.

Tooth wear was recorded according to Smith (1984), who allocated a score from 1 to 8 to quantify the occlusal wear for incisors, premolars and molars. The third molar was not scored as its wide variability in the eruption time across human populations might influence the wear degree (Schour \& Massler, 1941; Harris, 2007).

Average wear scores for males and females were calculated for each tooth category by combining the left and right sides, and the upper and lower dentitions, if at least one element was present for each tooth category. The individual index is the average of the all teeth recorded. Analysis was performed on all individuals.

\section{Statistical analysis}

The Chi-square test was used to determine the statistical significance with respect to the frequencies between samples and sexes. Fisher's exact test was used for smaller samples $(<5)$. In all cases the result was considered significant if the p-value was lower than 0.05 . All statistical analyses were conducted using the free program PAST version 4 (Hammer, Harper, \& Ryan, 2001).

\section{Results}

\section{Demographic distribution}


In total, the individuals brought to light from the trenches of Alghero, dated to the plague outbreak of 1582-83, are 180, of which 96 are adults and 84 subadults. Among the adults 53 are females (55.2\%), 36 males $(37.5 \%)$, and 7 of undetermined sex $(7.3 \%)$.

As for the biological profile of the entire sample, $47.8 \%$ of the individuals are subadults; $4.4 \%$ are infants in the first two years of life; $8.9 \%$ are infants aged between 2 and 6 years with prevalent deciduous teeth, $20 \%$ are in their late childhood with deciduous and permanent mixed dentition, and $14.4 \%$ are adolescents with permanent teeth. $52.5 \%$ of the sample is represented by adult individuals with a higher prevalence of female individuals (sex ratio, M:F=0.7), of which $25(13.9 \%)$ are aged between 20 and 25 years, $36(20 \%)$ between 26 and 35 years, $28(15.6 \%)$ between 36 and 45 years, and $5(2.8 \%)$ between 46 and 55 years. Therefore, the highest peak of mortality corresponds to the age range between 7 and 12 years, with a second age group between 26 and 35 years.

Out of the 180 individuals considered, 12 presented a completely or largely not-preserved dentition, and 8 children were excluded as they belong to the $0-2$ age range. Therefore, 160 subjects ( 81 adults and 79 subadults) were suitable for dental examination. The adult sample is composed by 30 males, 46 females, and 5 of undetermined sex (see Table 1).

\section{Caries}

\section{Adults}

In the whole assemblage, $14.6 \%$ of teeth are affected by caries, equally distributed in both sexes. Indeed, as shown in Table 2, the caries rate is almost the same in females, males and individuals of undeterminable sex. The Chi-square test suggests no statistical differences between the two sexes $(p=1.00)$. Similarly, the prevalence of caries per individual (Tab. 2) is very similar in both sexes, with a total frequency of $79.5 \%$ of the affected individuals; also in this case the Chi-square test shows no statistical differences between the two sexes $(p=0.94)$. The majority of affected teeth present one lesion, but $52(18.3 \%)$ teeth are affected by two or more caries. In Table 2 the frequency of caries by 
tooth types is presented. In general, an increasing frequency from the anterior teeth to the premolars and molars, which exhibit the highest values, can be observed.

Considering the differences between sexes, females show a higher frequency of caries in the anterior teeth and first premolars, and lower values in the second premolars compared to males; on the contrary, males exhibit a slightly higher frequency of caries in molars compared to females (Fig. 2). Table 3 shows the distribution of caries in age categories: the adult individuals were divided into three age groups to fit the sample in homogenous and comparable sub-samples. In general, an increase in the frequency of caries can be observed between the 20-29 age range (10\%) and the 30-39 and 40+ age ranges (19\% and $18.3 \%$ respectively). A statistically significant difference $(\mathrm{p}<0.001)$ was observed only between the first two age range classes (29-29 vs 30-39). This difference is exclusively due to the contribution of the variability in carious frequencies by age in the female sample, since the male frequencies are very similar in all age categories (Fig. 3).

Table 4 shows the location and severity of caries in adult individuals. The majority of caries affects the crown (69.7\%), followed by the dental neck $(26.2 \%)$, while the roots are rarely affected $(4.1 \%)$. If we consider the differences between sexes, the crown is slightly less affected in females than in males (67.5\% vs $73.4 \%)$, and the neck is slightly more affected (30\% vs $19.4 \%)$. As concerns caries location, the contact areas between neighboring teeth (interproximal) are the sites presenting the most frequent lesions $(49.2 \%)$, followed by the occlusal surface $(34.3 \%)$, whereas the buccal and lingual caries are very rare (14.4\% and $2.1 \%$ respectively). Both sexes exhibit similar values in all surfaces. In terms of severity, the majority of carious lesions are superficial (grade 1, 42.3\%), followed by those with dentine involvement (grade 2, 23.2\%) and with dental canal involvement (grade 3, 22.7\%), and by those with crown destruction (grade 4, 11.7\%). Considering the differences in severity between sexes, grade 1 and grade 3 caries present a minimal difference, whereas males are slightly more affected by grade 2 caries compared to females (25.9\% and $23 \%$, respectively); females are slightly more affected by grade 4 caries compared to males (13\% and $9.4 \%$, respectively). 


\section{Subadults}

Subadult individuals in the Alghero population are also affected by caries. Table 5 shows the frequency of total teeth affected by caries in the subadult subsample $(9.4 \%)$, with evidence of carious lesions also among children between 2 and 6 years of age $(6.8 \%)$. As for the frequency of caries calculated on individuals, $69.8 \%$ of subadults are affected. A significant increase was observed between the 2-6 age range and the 7-12 age range, with doubling of the individuals affected (37.5\% and $78.6 \%$ respectively); the values remain similar during adolescence $(69.8 \%)$.

As for the differences between deciduous and permanent dentition, $9.4 \%$ of teeth in subadults are affected by caries, of which $59.5 \%$ are deciduous and $40.5 \%$ are permanent teeth. Therefore, $21.2 \%$ of deciduous teeth and $5.2 \%$ of permanent teeth are affected, as can be seen in Table 5 .

The majority of teeth affected present one caries $(80.2 \%)$, but seven deciduous teeth and 15 permanent teeth are affected by two or more lesions.

Table 6 reports the location and severity of caries in subadults. Most caries affect the crown (86.1\%), followed by the dental neck $(13.1 \%)$, while the roots are rarely affected $(0.7 \%)$, with a similar trend when comparing the deciduous and permanent dentition. On the contrary, a marked difference was observed for the surfaces of a carious attack: interproximal caries are the most prevalent in deciduous teeth $(87 \%)$, whereas the occlusal surface shows the highest frequency in the permanent teeth (75.8\%). The buccal and lingual caries are rare in both deciduous and permanent teeth $(4.4 \%$ and $1.5 \%$ respectively). As concerns the severity of the carious lesions, in the deciduous teeth similar values are observed for superficial caries (grade 1), for lesions involving the dentine (grade 2), and for those affecting the dental pulp (grade 3) with $29.6 \%, 32.4 \%$ and $33.8 \%$ respectively. By contrast, $80.3 \%$ of the permanent teeth are affected by superficial caries (grade 1), followed by lesions involving the dental pulp and the dentine (10.6\% and $9.1 \%$ respectively). Caries with complete destruction of the crown (grade 4) are rare (2.2\%) in both dentitions. 
Moderate and severe periodontal disease (grades 2-3) affects half of the population of Alghero (50.7\% of adult individuals, Table 7). In both sexes a significant increase of this condition was observed with advancing age, with similar values for the 30-39 and 40+ age ranges for females and higher values in the $30-39$ age range compared to the $40+$ age range in males. In total, $47.6 \%$ of females and $57.7 \%$ of males with observable maxilla and/or mandible are affected by moderate and severe (grades 2-3) alveolar resorption. As for the differences between sexes, there is no statistically significant difference between females and males in the most severe form of the disease (grades 2-3) $(p=0.41)$.

Table 8 shows the frequencies of abscesses by alveoli and by individuals. Abscesses are not particularly frequent in the population of Alghero; in fact, only $1 \%$ of alveoli and $17.5 \%$ of individuals are affected. If we compare the frequency between sexes, it is evident that males are more affected than females, with $1.7 \%$ and $0.5 \%$ of affected alveoli respectively. The Chi-square test suggests a statistical difference between the two sexes $(p=0.02)$. In terms of frequency calculated on individuals, $27.3 \%$ of males and $11.8 \%$ of females are affected by abscesses; Fisher's exact test records no statistical differences between the two sexes $(p=0.16)$.

AMTL frequencies calculated by alveoli are similar in both sexes, with $9.3 \%$ in females and $8.4 \%$ in males, for a total of $8.5 \%$ teeth lost during life (Table 8 ). The Chi-square test suggests no statistical differences for AMTL between the two sexes $(p=0.98)$. Considering the frequency on individuals, males appear slightly more affected than females (58.6\% and 53.5\% respectively), with no statistical differences between sexes $(p=0.98)$ (Table 8$)$. The distribution of AMTL by age groups is shown in Table 9: teeth are mostly lost in the 30-39 age range and after the age of 40, whereas the prevalence is very low in both sexes under 30 years of age (Fig. 4). The comparison between males and females in each age group shows variable differences, but the Chi-square test indicates statistically significant differences only in the 20-29 age range, in which females are more affected than males $(\mathrm{p}=0.002)$. Calculus deposits are very widespread in the Alghero population: $90.5 \%$ of individuals are affected with slight differences between sexes (93.3\% of females and $96.7 \%$ of males are affected), and with 
equal distribution between the mild and the severe form. In the subadult subsample, calculus is observed in $52.2 \%$ of the individuals, mostly in mild form (Table 10).

\section{Dental wear}

The mean value of wear score was calculated by tooth category (anterior, premolar, and molar teeth, upper and lower teeth together). Table 11 shows the results for the different age groups.

As expected, dental wear is age-associated and increases in older individuals. Average wear slightly increases from the anterior toward the posterior teeth in both sexes and in all age ranges; the molars demonstrate the heaviest wear rates (Table 11).

Considering only molars, both in males and females the majority of individuals presents moderate wear (Table 12). The Chi-square test and Fisher's exact test were applied to verify differences between sexes in the low grades (1-3), moderate grades (4-5), and high grades (6-8). Although males exhibit patterns of wear that are slightly higher than those of females, no statistically significant sex differences were found in dental wear $(p=0.16 ; p=0.50 ; p=0.30$ respectively). $36 \%$ of the adult population exhibits low rates of attrition (grades 1-3), 52\% moderate rates (grades 4-5) and 12\% severe rates (grades 4-5). No individuals in both sexes show grade 8 molars (Table 12).

\section{Discussion}

This is the first study conducted on a large skeletal population from Sardinia. In fact, no previous studies have been specifically addressed to the dental pathologies of skeletal remains from the island; some investigations were carried out on a limited number of individuals from different chronological periods and have reported rough data related to dental health, which cannot be compared with the study proposed here (i.e. Bandiera, Mazzarello, Pirino, \& Montella, 2000; Germanà, 1995; Martella, Floris, \& Usai, 2014; Usai, Calò, Usai, \& Spiga, 2017; Usai, Floris, \& Salvi, 2016). Therefore, as there is no useful information available from any period of time in Sardinia, we compared our data with those of populations belonging to the same period but from different geographical contexts, 
especially from Mediterranean regions; in particular, we considered samples from northern Spain, (Lopez, Garcia-Vazquez, \& Dopico, 2011), southern France (Chazel, Valcarcel, Tramini, Pelissier, \& Mafart, 2005), and the Coimbra collection (Wasterlain, Hillson, \& Cunha, 2009).

The cemetery of Alghero is a catastrophic sample reflecting the plague outbreak that ravaged the city in 1582-1583. Attritional mortality profiles generally exhibit a peak in certain age and sex groups, in particular during infancy and early childhood, and they gradually increase throughout adulthood. The demographic profile of the cemetery of Alghero reflects a catastrophic mortality trend, since most age and sex groups are equally distributed as they were equally susceptible to plague. This fact is particularly evident for the subadult population, because young individuals and many older children are present in the trenches of Alghero, in contrast with the model of an attritional cemetery (Margerison \& Knusel, 2002). As to the adults, a slight prevalence of females was observed in the demographic composition of the sample. A study regarding the London Black Death cemetery in 1349-1350, aimed to evaluate the effects of sex on mortality risk during the plague epidemic suggested that there was a higher excess of mortality in males than in females. This was the effect of a previous physiological stress on risk of death that was stronger in males (DeWitte, 2010). The prevalence of females in the cemetery of Alghero could indicate a major susceptibility of females to plague in this population.

Since the osteoarchaeological material of Alghero comes from a catastrophic cemetery, it can be considered representative of the original living population. As such, the dental pathologies observed in this sample are likely to reflect the dental health status of this human group.

However, there are limits to these assumptions proposed by "The Osteological Paradox", which should be evaluated (Wood, Milner, Harpending, \& Weiss, 1992). The first issue, refering to the nonstationarity of demography, implies that populations are influenced by migratory processes and possible changes in growth, fertility and mortality rates and the population of Alghero was certainly not stationary, as repopulation of the city with groups coming from different areas of the continent are historically attested (Budruni, 2010). 
The second issue, the selective mortality, is related to the fact that the skeletal remains are not representative of the entire population but only include the individuals with the highest frailty and therefore cannot be expected to provide a perfect cross-section of the living population; in fact, some authors have demonstrated that the Black Death did not kill indiscriminately, but was selective with respect to frailty, although probably not as strongly selective as normal mortality (DeWitte \& Wood, 2008).

The third issue, the hidden heterogeneity in risk, refers to the idea that the individuals of the original population might have had variable susceptibility to disease and/or death, which are difficult or impossible to assess. In conclusion, the data should be carefully examined, taking all these limits into consideration.

In the adult population of Alghero, caries is detected in $14.6 \%$ of teeth and in $79.5 \%$ of individuals. These values are similar to those registered in other post-Medieval samples (Boyle \& Keevil, 1998; Brikley, Buteux, Adams, \& Cherrington, 2006; Mant \& Roberts, 2015). For example, in a $16^{\text {th }}-17^{\text {th }}$ century sample from southern France $18.6 \%$ of teeth are affected by caries (Chazel, Valcarcel, Tramini, Pelissier, \& Mafart, 2005) and in three Spanish samples between the $16^{\text {th }}$ and $18^{\text {th }}$ centuries the prevalence of carious teeth is $11.6 \%$ (Lopez, Pardiñas, Garcia-Vazquez, \& Dopico, 2012). Higher frequencies of caries are typically found after the $18^{\text {th }}$ century when refined sugar became available to all socioeconomic groups (Müller \& Hussein, 2017); for example two $18^{\text {th }}$-early $19^{\text {th }}$ century AD samples from London show $21.5 \%$ and $26.5 \%$ of prevalence by tooth and of $79.5 \%$ and $78.9 \%$ by individual (Mant \& Roberts, 2015); in the Portuguese Identified Skeletal Sample from Coimbra (19th$20^{\text {th }}$ centuries) $27.9 \%$ of teeth and $92.6 \%$ of individuals are affected by cavitated lesions (Wasterlain, Hillson, \& Cunha, 2009).

Several diachronic studies were performed to investigate patterns of dental caries. As a general trend, an increase was observed over time in the rates of dental caries, with higher values in the postMedieval period, associated with a change in tooth decay location from the neck to the interproximal and occlusal surfaces (Brothwell, 1959; Hardwick, 1960; Hillson, 2005; Moore \& Corbett, 1975). 
Consistently, the location of carious lesions in the population of Alghero are typical of the postMedieval period. Such lesions exhibit low rates of carious attack at the root and at the dental neck in favor of the crown, and at buccal and lingual surfaces in favor of interproximal and occlusal surfaces. This trend was explained with a change in the dietary habits after the Middle Ages, when the consumption of soft foodstuffs increased, so as to determine a reduction of the tooth attrition rate and of the polish power of abrasive foods on the tooth surfaces (Maat, 2001). By contrast, consumption of coarse foods, typical of many ancient populations, increased occlusal wear, which in turn induced compensative eruption of teeth, thus favoring cervical and root caries (Hillson, 2008).

As for the diet adopted in Alghero in this period, it is attested that, with the exception of the aristocracy who had access to a variety of foods including a good protein intake, the majority of the population had a diet based on bread, soups of herbs and vegetables, some fish during the summer, wild and cultivated fruits and sometimes meat; on some occasions, the shepherds and farmers could consume parts of cattle that had died for natural causes and poultry bred for family consumption (Budruni, 2010; Milanese, Deiana, Filigheddu \& Rovina, 2000). According to an inquiry conducted in Sardinia in 1572, 1,050,000 heads of cattle were present, among which $57 \%$ was represented by sheep, $19 \%$ by goats, $14.5 \%$ by cattle, and the remaining $9.5 \%$ by swine and equine in equal parts. As for the agricultural resources, $73.5 \%$ of the cereals cultivated on the island was represented by wheat (Anatra, Mattone, \& Turtas, 1989). The cultivation of sugar cane was introduced in Sardinia at the beginning of the $17^{\text {th }}$ century AD (Anatra, Mattone, \& Turtas, 1989).

In the population of Alghero there are no significant differences between males and females in the frequency of caries. This was observed also in other post-Medieval series (Corbett and Moore, 1976; Saunders et al., 1997), contrary to the common general trend revealed by studies of past populations, according to which women appear to be more affected by caries than men (Hillson, 2000; Larsen, 1997; Lukacs \& Thompson, 2008). Hovewer, in the population of Alghero carious lesions seem to be age-related in the female population, whereas no increase in caries was observed in males with progressing age. Also other studies on caries in historical (Miliauskiene \& Jankauskas, 2015) and 
living populations (Hillson, 2000; Lukacs \& Largaespada, 2006) reported higher age-specific scores for women than for men. These disparities between sexes may be related to differences in diet in the two sexes, as males are more likely to have eaten more meat and females more vegetables and carbohydrates. Furthermore, the biochemical composition of saliva is altered by hormonal fluctuations during events such as puberty, menstruation and pregnancy, making the oral environment significantly more cariogenic for women (Lukacs, 2008; Lukacs, 2011; Lukacs \& Largaespada, 2006). Post-Medieval data evidences the fundamental role of diet in the onset of carious lesions; in fact, independent of the physiological differences predisposing females to develop this pathology, the consumption of cariogenic foods may have increased the chances of males to suffer from caries (Mant \& Roberts, 2015).

The subadults of the population of Alghero exhibit lower frequencies of carious lesions compared to the adult individuals ( $9.4 \%$ and $14.6 \%$ of teeth respectively). The difference is statistically significant $(\mathrm{p}<0.005)$. Studies on dental caries in Medieval and post-Medieval English samples found that the prevalence of caries in children is usually low in the early and later Medieval periods, with respectively $3.5 \%$ and $4.5 \%$ of deciduous teeth with caries. Caries begins to rise in the $15^{\text {th }}$ century, with widespread availability of refined foods (Moore \& Corbett, 1973). In the $17^{\text {th }}$ century, when sugar cane was largely consumed by the population, the dental caries rate in deciduous teeth reached 28.5\% (Corbett \& Moore, 1976; Moore \& Corbett, 1973, 1975), a frequency similar to that observed in the deciduous teeth from Alghero (21.2\%), suggesting a cariogenic diet in the Sardinian children. As for the other oral health indicators, the results suggest analogous dental health for both sexes: no statistically significant differences between sexes were observed in the frequency of periodontal disease, abscesses calculated on individuals, AMTL, and calculus. The only exception is represented by the frequency of abscesses calculated by alveolus, which showed a statistically significant prevalence in males. The overall trend of dento-alveolar diseases seems to suggest a homogeneous pattern confirming that both sexes were similar in oral hygiene practices and in food access. 
The most severe forms of periodontal disease (grades 2-3) in the Alghero population affect 50.7\% of individuals. In other contemporary samples the values are lower, e.g. in the $16^{\text {th }}-18^{\text {th }}$ centuries periodontitis in northern Spain affected $20-35 \%$ of the population (Lopez, Garcia-Vazquez, \& Dopico, 2011). As mentioned above, periodontal disease is often associated with softer food types. Sex differences in periodontal disease observed in the archaeological samples revealed higher frequencies and greater severity of periodontal disease in males than in females, associated with physiological and behavioral differences between sexes (DeWitte \& Bekvalac, 2011; Shiau \& Reynolds, 2010). In Alghero this parameter also evidenced a uniformity between sexes. The frequency of periodontal disease can be associated with poor oral hygiene. In fact, individuals with plaque deposits on their teeth may experience gingivitis, or the inflammation of the oral soft tissues, which may lead to alveolar resorption. Periodontal diseases can also concur to cause AMTL (Hillson, 2005).

Abscesses in the Alghero sample show low rates, since only $1 \%$ of alveoli and $17.5 \%$ of individuals are affected. In the contemporary skeletal series dated back to the $16^{\text {th }}-18^{\text {th }}$ centuries AD of northern Spain, the frequency is similarly low, as it ranges between $0.8 \%$ and $7.8 \%$ by individual (Lopez,Garcia-Vazquez, \& Dopico, 2011). The development of abscesses is strongly related to carious lesions; in fact, with the progression of a caries, an infection can spread through the dental pulp extending to the bone and to the soft tissue around the apex of the root (Hillson, 2001). A low prevalence of abscesses is probably linked to the low aggressiveness of dental caries: indeed, the majority of lesions in the adult population of Alghero is superficial (42.3\%), whereas perforations involving the dental pulp and causing a complete destruction of the crown are $22.7 \%$ and $11.7 \%$ respectively. The most severe carious lesions are likely to have been treated with tooth extraction (Hussain \& Khan, 2016), thus preventing the development of infection. Indeed, more than half of the population had teeth that had been lost ante-mortem: AMTL was observed in $53.8 \%$ of individuals and $8.5 \%$ of alveoli. Although a higher prevalence of $37.2 \%$ by alveolus was observed in the Modern Age sample from Portugal (late $19^{\text {th }}$-early $20^{\text {th }}$ centuries) (Wasterlain, Hillson \& Cuhna, 2009), it is 
difficult to establish the exact cause of AMTL in skeletal material. However, the high dental caries rate in the population of Alghero may suggest that complications of caries could represent the main cause for AMTL. In fact, tooth decay showed the same trend as AMTL in the distribution by age with a significant increase in the middle and mature adults. Finally, extraction was the only effective way to treat a tooth-ache in those times (Hussain \& Khan, 2016).

In the population of Alghero the presence of dental plaque and poor oral hygiene is testified by widespread calculus, which affects $90.5 \%$ of the adult population with $45.2 \%$ of the individuals showing strong deposits; subadults are also affected (52.2\%) but mainly in mild form. Other postMedieval populations generally exhibit high rates of calculus as well (Lopez,Garcia-Vazquez, \& Dopico, 2011; Miliauskiene \& Jankauskas, 2015; Petersone-Gordina, Roberts, Millard, Montgomery, \& Gerhards, 2018). Calculus should be related to the frequency of caries and of periodontal disease. Some studies have evidenced that high calculus rates combined with low caries rates are characteristic of populations with a diet high in proteins and low in carbohydrates; conversely, high calculus prevalence combined with high caries rates suggests that the diet was rich in carbohydrates and low in proteins (Slaus, Bedic, Sikanjic, Vodanovic, \& Kunic, 2011). Calculus and periodontal disease are interdependent since the occurrence and severity of the former favors the colonisation of the alveolar bone by the bacteria from the plaque (Griene, Kuba, \& Irish, 2005).

In the population of Alghero dental wear is moderate, with an average score of 4 at pooled sexes and with no statistically significant differences between males and females, confirming the same type of food for the overall population. Other samples from the Modern Age showed similar patterns of dental wear with an average moderate wear (Lopez,Garcia-Vazquez, \& Dopico, 2011; Miliauskiene \& Jankauskas, 2015). Moderate wear suggests that the population had access to highly processed refined food instead of coarse food. An improvement in the technology of flour making reduced the amount of grit in flour and decreased the abrasiveness of food (Larsen 1997). At the same time a correlation was observed between abrasion decrease and caries increase: as a matter of fact, the abrasiveness of 
food naturally cleans the teeth by removing both food and bacteria and thus helping reduce the number of occlusal caries (Larsen, 1997).

The patterns of dental pathologies recorded in the population of Alghero suggest that the diet was rich in soft and refined food, with a prevalence of carbohydrates and cariogenic foodstuff; the effects of the diet were associated with a lack of oral hygiene, which was the rule in this period. In fact, oral hygiene and dentistry developed only throughout the $18^{\text {th }}$ and $19^{\text {th }}$ centuries, whereas dentistry in the previous periods was commonly practised by barbers and charlatans; the only common dental procedure for carious teeth was tooth extraction, and dental care was limited to the use of herbal remedies and blood-letting; oral hygiene practices were substantially irrelevant (Weinberger, 1948). The patterns of dental health observed in the Alghero population are in accordance with the data observed in other Modern Age samples, showing increased prevalence of dento-alveolar diseases according to a less abrasive diet and an increase in cariogenic and refined carbohydrate consumption, as documented during the transition from the Middle Ages to the Modern Age.

\section{Conclusions}

The sample of Alghero comes from a catastrophic cemetery referable to the plague outbreak of 15821583, and therefore can provide an unbiased picture of the demographic and epidemiological characteristics of the original living population.

This study reveals that the population of Alghero was affected by a high rate of tooth decay, with similar values for the adults of both sexes and for subadults, with a prevalent location in the occlusal and interproximal surfaces of the crown. Although the caries rate is lower with respect to the frequencies observed in the $17^{\text {th }}-18^{\text {th }}$ centuries, when refined sugar became available to a large part of populations, the pattern found at Alghero is typical of post-Medieval populations which assumed a diet rich in soft, refined, and cariogenic food prevalently based on carbohydrates. The majority of caries are superficial, and this can explain the low rates of abscesses recorded. The other dental indicators further support this conclusion and demonstrate scarce dental hygiene practices, as 
confirmed by high frequencies of periodontal disease, AMTL, and calculus. Tooth wear is overall moderate, probably for the prevalent consumption of processed refined food. No sexual differences are observed in all dental indicators, evidencing equal and uniform access to diet and dental hygiene for both males and females. Subadults exhibit moderate rates of caries and half of the subsample is also affected by mild calculus. The patterns of dental indicators are similar to those observed in other European Modern populations.

\section{Author statement}

Valentina Giuffra: Conceptualization, Methodology, Data analysis and interpretation, Formal analysis, Writing- Original draft preparation, Final approval of the manuscript. Simona Minozzi: Methodology, Data analysis and interpretation, Writing - review \& editing, Final approval of the manuscript. Marco Milanese: Acquisition of data, Supervision, Writing - Review \& Editing, Final approval of the manuscript.

\section{Conflict of interest}

All authors declare no conflict of interest.

\section{Funding}

This study did not receive any specific grant from funding agencies in the public, commercial, or not-for-profit sectors.

\section{References}

Afrianty, I., Nasien, D., Kadir, M.R.A., \& Haron, H. (2013). Determination of gender from pelvic bones and patella in forensic anthropology: a comparison of classification techniques. First International Conference on Artificial Intelligence, Modelling \& Simulation, 3-7. 
Akcali, A, \& Lang, N.P. (2018). Dental calculus: the calcified biofilm and its role in disease development. Periodontology 2000, 76, 109-115.

Alt, K.W., Turp, L.C., \& Wachter,R. (1998). Periapical Lesions - Clinical andAnthropological Aspects. In K.W. Alt, F.W. Rosing, \& M. Teschler-Nicola (Eds.). Dental Anthropology (pp. 247276). Wien: Springer-Verlag.

Anatra, B., Mattone, A., \&Turtas, R. (1989). L'età Moderna. Dagli Aragonesi alla fine del dominio spagnolo. Milano: Jaca Book.

Bandiera, P., Mazzarello, V.L., Pirino, A., \& Montella, A. (2000). Morphologic and paleopathologic remarks about teeth of Sardinian residents from 1300 B.C. to 200 A.D. Italian Journal of Anatomy and Embryology, 105 (suppl 1), 14.

Berrizbeitia, E.L., (1989). Sex determination with the head of the radius. Journal of Forensic Sciences, 34, 1206-1213.

Bizot, B., Castex, D., Reynaud, P., \& Signoli, M. (eds). (2005). La saison d'une peste (AvrilSeptembre 1590). Le cimetière des Dédons à Lambesc. Paris: CNRS.

Boyle, A., \& Keevil, G. (1998). "To the praise of the dead, and anatomie": the analysis of postmedieval burials at St. Nicholas, Sevenoaks, Kent. In M. Cox (Ed.).Grave Concerns: Death and Burial in England 1700-1850 (pp. 85-99). York: Council for British Archaeology.

Brickley, M., Buteux, S., Adams, J., \& Cherrington, R. (2006). St. Martin's Uncovered: Investigations in the churchyard of St. Martin's-in-the-Bull Ring, Birmingham, 2001. Oxford: Oxbow.

Brooks, S., \& Suchey, J.M. (1990). Skeletal age determination based on the os pubis: a comparison of the Acsádi-Nemeskéri and Suchey-Brooks methods. Human Evolution, 5, 227-238.

Brothwell, D.R. (1959). Teeth in earlier human populations. Proceedings of the Nutrition Society, 18, $59-65$.

Brothwell, D.R., (1981). Digging up Bones. Oxford: Oxford University Press.

Budruni, A. (2010). Storia di Alghero. Il Cinquecento e il Seicento. Alghero: Edizioni del Sole. 
Buikstra, J.E., \& Ubelaker, D.H. (1994). Standards for data collection from human skeletal remains. Fayetteville, Arkansas: Archeological Survey Research Series.

Caselitz, P. (1998). Caries - Ancient Plague of Humankind. In K.W. Alt, F.W. Rosing, \& M. TeschlerNicola (Eds.). Dental Anthropology (pp. 203-226). Wien: Springer-Verlag.

Chazel, J.C., Valcarcel, J., Tramini, P., Pelissier, B., \& Mafart, B. (2005). Coronal and apical lesions, environmental factors: study in a modern and anarchaeological population. Clinical Oral Investigations, 9, 197-202.

Corbett, E., \& Moore, W. J. (1976). Distribution of dental caries in ancient British populations IV: the $19^{\text {th }}$ century. Caries Research, $10,401-414$.

Cripps, S. (1984).Aetiology, Periodontal Disease, Recognition, Interception and Prevention.New York: Quintessence.

De Witte SN. (2010). Sex differentials in frailty in Medieval England. American Journal of Physical Anthropology, 143, 285-297.

DeWitte, S.N., \& Bekvalac, J. (2011). The association between periodontal disease and periosteal lesions in the St. Mary Graces cemetery, London, England A.D. 1350-1538. American Journal of Physical Anthropology, 146, 609-618.

DeWitte, S.N., \& Wood, J.W. (2008). Selectivity of black death mortality with respect to preexisting health. Proceedings of the National Academy of Sciences USA, 105, 1436-1441.

Ferembach, D., Schwidetzky, J., \& Stloukal, M. (1980). Recommendations for age and sex diagnosis of skeletons. Journal of Human Evolution, 9, 517-549.

Fujita, H., Suzuki, T., Shoda, S., Kawakubo, Y, Ohno, K., Giannakopoulou, P., \& Harihara, S. (2013). Contribution of ante-mortem tooth loss (AMTL) and dental attrition to oral palaeopathology in the human skeletal series from the Yean-ri site, South Korea. International Journal of Archaeology, 1, $1-5$.

Gasner, N.S., \& Scure, R.S. (2020). Periodontal disease. StatPearls [Internet]. Treasure Island (FL): StatPearls Publishing. 
Germanà, F. (1995). L'uomo in Sardegna dal paleolitico fino all'età nuragica. Sassari: Delfino Editore.

Griene, T.R., Kuba, C.L., \& Irish, J.D. (2005). Quantifying calculus: A suggested new approach for recording an important indicator of diet and dental health. Homo, 56, 119-132.

Hammer, Ø., Harper, D.A.T., \& Ryan, P.D. (2001). PAST: paleontological Statistics software package for education and data analysis. Palaeontologia Electronica, 4, 9.

Hardwich, J.L. (1960). The incidence and distribution of caries throughout the ages in relation to the Englishman's diet. British Dental Journal, 108, 9-17.

Harris, E.F. (2007). Mineralization of the mandibular third molar: a study of American blacks and whites.American Journal of Physical Anthropology, 132, 98-109.

Hillson, S. (2000). Dental pathology. In M.A. Katzenberg, \& S. R. Saunders (Eds.). Biological anthropology of the human skeleton (pp. 249-286). New York: Wiley-Liss.

Hillson, S. (2005). Teeth. Cambridge: Cambridge University Press.

Hillson, S. (2008). The current state of dental decay. In J.D. Irish, \& G.C. Nelson (Eds.). Technique and application in dental anthropology (pp. 111-135). Cambridge: Cambridge University Press.

Hillson, S., (1996). Dental Anthropology. Cambridge: Cambridge University Press.

Hussain, A., \& Khan F. A. (2016). History of dentistry. Archives of Medicine and Health Sciences, 2, 106-110.

Huynh, H.T.T., Verneau, J., Levasseur, A., Drancourt, M., \& Aboudharam, G. (2016). Bacteria and archaea paleomicrobiology of the dental calculus: a review. Molecular Oral Microbiology, 31, 23442.

İşcan, Y.M., \& Loth, S.R. (1985). Age estimation from the rib by phase analysis: white females. Journal of Forensic Sciences, 30, 853-864.

İşcan, Y.M., Loth, S.R., \& Wright, R.K. (1984). Age estimation from the rib by phase analysis: white males. Journal of Forensic Sciences, 29, 1094-1104. 
İşcan, YM, Steyn, M. (2013). The Human skeleton in Forensic Medicine (3rd ed.). Springfield, IL: Charles C. Thomas.

Kaidonis, J.A. (2008). Tooth wear: the view of the anthropologist. Clinical Oral Investigations, 12 (Suppl 1), 21-26.

Krogman, W., \& İşcan, Y.M. (1986). Human skeleton in forensic medicine. Springfield: Charles C. Thomas.

Larsen, C.S. (1997). Bioarchaeology: interpreting behavior from the human skeleton. Cambridge, Cambridge University Press.

Larsen, C.S., Shavit, R., \& Griffin, M.C. (1991). Dental caries evidence for dietary change: an archaeological context. In M.A. Kelley, \& C.S. Larsen (Eds.). Advances in dental anthropology (pp.179-202). New York: Wiley-Liss.

Larsen, C.S., Shavit, R., \& Griffin, M.C. (1991). Dental caries evidence for dietary change: an archaeological context. In Kelley, A., \& C.S. Larsen (Eds.). Advances in dental anthropology (pp. 179-202). New York: Wiley-Liss.

Lopez, B., Garcia-Vazquez, E., \& Dopico, E. (2011). Dental indicators suggest health improvement associated with increased food diversity in Modern Age Spain. Human Ecology, 39, 527-534.

Lopez, B., Pardiñas, A. F., Garcia-Vazquez, E., \& Dopico, E. (2012). Socio-cultural factors in dental diseases in the Medieval an early Modern Age of northern Spain. Homo, 63, 21-42

Lovejoy, C.O., (1985). Dental wear in Libbean population: its functional pattern and role in the determination of adult skeletal age at the death. American Journal of Physical Anthropology 68, 4756.

Lovejoy, C.O., Meindl, R.S., Pryzbeck, T.R., \& Mensforth, R.P., (1985). Chronological metamorphosis of the auricolar surface of the ilium: a new method for the determination of adult skeletal age at death. American Journal of Physical Anthropology 68, 15-28. 
Lukacs, J.R, \& Thompson, LM. (2008). Dental caries prevalence by sex in prehistory: magnitude and meaning. In Irish, J.D., \& G.C., Nelson (Eds.). Technique and application in dental anthropology (pp. 136-177). Cambridge: Cambridge University Press.

Lukacs, J.R. (2008). Fertility and agriculture accentuate sex differences in dental caries rates. Current Anthropology, 49, 901-14.

Lukacs, J.R. (2011). Sex differences in dental caries experience: Clinical evidence, complex etiology. Clinical Oral Investigations, 15, 649-656.

Lukacs, J. R., \& Largaespada, L.L. (2006). Explaining sex differences in dental caries prevalence: saliva, hormones, and "life-history" etiologies. American Journal of Human Biology, $18,540-55$.

Maat, G.J. (2001). Diet and age-at-death determinations from molar attrition. A review related to the Low Countries. The Journal of Forensic Odontostomatology, 19, 18-21.

Manconi, F., (1994). Castigo de Dios. La grande peste barocca nella Sardegna di Filippo IV. Roma: Donzelli Editore.

Mant, M., \& Roberts, C. (2015). Diet and dental caries in post-Medieval London. International Journal of Historical Archaeology, 19, 188-207.

Margerison, B.J., \& Knusel, C.J. (2002). Paleodemographic comparison of a catastrophic and an attritional death assemblage. American Journal of Physical Anthropology, 119, 134-143.

Martella, P., Floris, R., \& Usai, E. (2014). Primi dati osteologici su resti scheletrici provenienti da due tombe della Sardegna meridionale: Ingurtosu Mannu (Donori) e Sa Serra Masi (Siliqua). Annali dell'Università di Ferrara, 10, 68-73.

Milanese M., (2015). Aspetti del commercio catalano medievale in Sardegna. Sistemi di fonti e nuovi sguardi sulle fonti archeologiche in margine all'enclave di Alghero. In Gallinari L., \& F.S. Curull (Eds.). Tra il Tirreno e Gibiliterra. Un Mediterraneo iberico? (pp. 601-624). Cagliari: CNR.

Milanese M., Deiana A., Filigheddu R., \& Rovina D. (2000). Fonti archeologiche e archeobotaniche per la storia della vite e del vino nella Sardegna nord-occidentale (secc. XIV-XVII). In Da Passano 
M., Mattone A., Mele F., \& P.F. Simbula (Eds.). La vite e il vino. Storia e diritto (secoli XI-XIX) (pp. 531-577). Roma: Carocci.

Milanese, M., (2013). Alghero. Archeologia di una città medievale. Sassari: Carlo Delfino Editore.

Milanese, M., (Ed.) (2010). Lo scavo del cimitero di San Michele ad Alghero (fine XIII-inizi XVII secolo), campagna di scavo giugno 2008-settembre 2009. Pisa: Felici Editore.

Miliauskiene, Z., \& Jankauskas, R. (2016). Social differences in oral health: dental status of individuals buried in and around Trakai Church in Lithuania $\left(16^{\text {th }}-17^{\text {th }}\right.$ c.c. $)$. Anthropologischer Anzeiger 72: 89-106.

Miller, R.L., Gould, A.R., Bernstein, M.L., \& Read, C.J. (1995). General and oral pathology for the dental hygienist. St. Louis: Mosby.

Minozzi, S., \& Canci, A. (2015). Archeologia dei resti umani. Dallo scavo al laboratorio Roma: Carocci.

Moore, W. J., and Corbett, E. (1973). The distribution of dental caries in ancient British populations II, Iron Age, Romano-British and Mediaeval Periods. Caries Research, 7, 139-153.

Moore, W.J., \& Corbett, E. (1975). The distribution of dental caries in ancient British populations III, the 17th century. Caries Research, 9, 163-175.

Moore, W.J., \& Corbett, E. (1983). Dental and alveolar infection. In G.D. Hart (Ed.). Disease in Ancient Man (pp. 139-155). Toronto: Clark.

Müller, A., \& Hussein, K. (2017). Meta-analysis of teeth from European populations before and after the 18th century reveals a shift towards increased prevalence of caries and tooth loss. Archives of Oral Biology, 73, 7-15.

Petersone-Gordina, E., Roberts, C., Millard, A.R., Montgomery, J, \& Gerhards, G. (2018). Dental disease and dietary isotopes of individuals from St Gertrude Church cemetery, Riga, Latvia. PLOSone, 13, e0191757.

Rathee, M., \& Sapra, A. (2019). Dental caries. StatPearls [Internet]. Treasure Island (FL): StatPearls Publishing. 
Sanders, J.L., \& Houck, R.C. (2019). Dental abscess. StatPearls. [Internet]. Treasure Island (FL): StatPearls Publishing.

Saunders, S.R., De Vito, C., \& Katzenberg, M.A. (1997). Dental caries in nineteenth century Upper Canada. American Journal of Physical Anthropology, 104, 71-87.

Schaefer, M., Black, S., \& Scheuer, L. (2009). Juvenile osteology. A laboratory field manual. London: Academic Press.

Scheuer, L., \& Black, S. (2000). Developmental Juvenile Osteology. London: Academic Press.

Schour, L., \& Massler, M. (1941). The development of the human dentition. Journal of the American Dental Association, 28, 1153.

Shiau, H.J., \& Reynolds, M.A. (2010). Sex differences in destructive periodontal disease: exploring the biologic basis. Journal of Periodontology, 81, 1505-17.

Signoli, M., Chausserie-Lapree, J., \& Dutour, O. (1997). Etude anthropologique d'un charnier de la peste de 1720-1721 a Martigues. Prehistoire et Anthropologie Mediterraneennes, 4, 173-189.

Signoli, M., Chevé, D., Adalian P., Boetsch, G., \& Dutour, O., (2007). Peste: entre épidémie set Sociétés. Firenze: Firenze University Press.

Silva A.M. (1995). Sex assessment using the calcaneus and talus. Antropologia Portuguesa, 13, 107119.

Slaus, M., Bedic, Z., Sikanjic, P.R., Vodanovic, M., \& Kunic, A.D. (2011): Dental health at the transition from the Late Antique to the Early Medieval period on Croatia's Eastern Adriatic Coast. International Journal of Osteoarchaeology, 21, 577-590.

Smith, B.H. (1984). Patterns of molar wear in Hunter-gatherers and agriculturalists. American Journal of Physical Anthropology, 63, 39-56.

Sorgia, G. (1982). La Sardegna Spagnola. Sassari: Chiarella.

Stabholz, A., Soskolne, W.A., \& Shapira, L. (2010). Genetic and environmental risk factors for chronic periodontitis and aggressive periodontitis. Periodontology, 2000, 53, 138-153. 
Stermer Beyer-Olsen, E.M., \& Risnes, S. (1994). Radiographic analysis of dental development used in age determination of infant and juvenile skulls from a medieval archaeological site in Norway. Journal of Dental Research, 23, 257-266.

Stloukal, M., \& Hanakova, H. (1978). Die länge der Längsknochenaltslawischer. Bevölkerungen unter besonderer Berücksichtigung von Wachstumsfragen. Homo, 29, 53-69.

Strohm, T.F., Alt,K.W. (1998). Periodontal Disease - Etiology, classification and diagnosis. In K.W. Alt, F.W. Rosing, \& M. Teschler-Nicola (Eds.). Dental anthropology (pp. 227-246). Wien: SpringerVerlag.

Tzortzis, S., \& Signoli, M. (2009). Les tranchées des Capucins de Ferrières (Martigues, Bouches-duRhône, France). Un charnier de l'epidémie de peste de 1720 à 1722 en Provence. Comptes Rendus Palevol, 8, 749-760.

Ubelaker, D.H. (1989). Human skeletal remains: excavation, analysis, interpretation. Washington DC: Smithsonian Institute Press.

Usai, E., Calò, C.M., Usai, L., Gaudina, E., \& Spiga, C. (2017). Il materiale osteologico umano proveniente da tre tombe dei giganti presenti nel territorio di Villamassargia (Sardegna, Italia). Antropo, 38, 13-23.

Usai, E., Floris, R., \& Salvi, D. (2016). Il materiale scheletrico umano proveniente dal cimitero di San Marcello, rinvenuto in occasione dello scavo del chiostro di San Francesco a Iglesias (CA) Italy. Anthrocom Online Journal of Anthropology, 12, 133-155.

Wasterlain, S.N., Hillson, S., \& Cunha, E. (2009). Dental caries in a Portuguese identified skeletal sample from the late 19th and early 20th centuries. American Journal of Physical Anthropology, 140, $64-79$.

Weinberger, B.W. (1948). An introduction to the history of dentistry. Volume 1, St. Louis C.V.: Mosby.

Wood, J.W., Milner, G.R., Harpending, H.C., \& Weiss, K.M. (1992). The osteological paradox: problems of inferring prehistoric health from skeletal samples. Current Anthropology, 33, 343-370. 


\section{Figures}

Figure 1. Map of Sardinia with the location of Alghero (A); trench 4 of the plague cemetery of Alghero referable to the outbreak of 1582-83 (B).

Figure 2. Caries frequency by sex and tooth type in adult individuals. In the "total sample" percentages, individuals of indeterminable sex are included; number of observations, details, and legend are reported in Table 2.

Figure 3. Caries frequency by sex in age categories in adult individuals. In the "total sample" percentages individuals of indeterminable sex are included; number of observations and details are reported in Table 3.

Figure 4. AMTL frequency by sex in age categories in adult individuals. In the "total sample" percentages, individuals of indeterminable sex are included; number of observations and details are reported in Table 9.

\section{Tables}

Table 1. Demographic distribution of the individuals analyzed for dental health $(\mathrm{N}=160)$ from the plague cemetery of Alghero.

Table 2. Distribution of carious teeth by sex and tooth type in adult individuals.

Legend: $\mathrm{N}=$ number of teeth/individuals affected by caries; Obs = observable teeth; $\mathrm{I}=$ incisor; $\mathrm{C}=$ canine; $\mathrm{P}=$ premolar; $\mathrm{M}=$ molar. $*$ Individuals with at least 14 not affected teeth are considered observable.

Table 3. Distribution of caries by sex in age ranges in adult individuals.

Table 4. Localisation and severity of the caries in females, males and individuals of undeterminable sex.

Table 5. Distribution of caries in age ranges in subadults by individual and by tooth. 
Table 6. Localisation and severity of the caries in deciduous and permanent teeth in subadults.

Table 7. Distribution of three degrees of severity of alveolar resorption by sex and age ranges.

Table 8. Frequencies by alveoli and by individuals of abscesses and teeth lost during life (AMTL).

Table 9. Distribution of AMTL in age ranges in adults ( $\%$ on alveoli plus isolated teeth).

Table 10. Distribution and severity of calculus by individual, in adults and subadults.

Table 11. Average wear score for males and females calculated for each tooth category. The mean value has been calculated for the upper and lower teeth together.

Table 12. Frequency of individuals with different grades of tooth wear in molars. 